\title{
FRESHWATER GAMMARUS SPECIES FROM EUROPE, NORTH AFRICA AND ADJACENT REGIONS OF ASIA (CRUSTACEA-AMPHIPODA)
}

\author{
PART II. GAMMARUS ROESELI-GROUP AND RELATED SPECIES
}

\author{
by
}

\author{
GORDAN S. KARAMAN \\ Biological Institute, Titograd, Yugoslavia
}

$\boldsymbol{\&}$

SJOUK PINKSTER

Institute of Taxonomic Zoology, University of Amsterdam, The Netherlands

\begin{abstract}
1) This part of the revision of the freshwater Gammarus species deals with the $G$. roeseli-group. Members of this artificial group are characterized by the presence of dorsal processes (carinae) on the metasome segments.

2) A historical review is given from the first description of G. roeseli and the taxonomic confusion that followed, to the start of this study when 3 species and at least 15 subspecies were known.

3) Where possible, the type material of all these taxa is re-examined and compared with hundreds of newly collected samples and material from all major museums in Europe.

4) In this study the same morphological characters are used as in the revision of the $G$. pulex-group (Karaman \& Pinkster, 1977). The variability of the various characters is discussed.

5) Complete descriptions and many illustrations are given of the males of all species, along with a key for their identification. Where necessary, figures are given of those details in which females differ from the males.

6) It is proved that $G$. triacanthus and its many subspecies must be considered synonymous with $G$. roeseli. $G$. argaeus stoiicevici is raised to specific rank. Four new species ( $G$. goedmakersae, G. mladeni, G. obnixus and $G$. pavo) are described, resulting in a total number of seven species within this group.

7) In many localities members of the $G$. roeseli-group have been found together with members of the $G$. pulex- or $G$. balcanicus-group. Experimental work on $G$. roeseli showed that in such cases $G$. roeseli is more eurybiont than the members of the $G$. pulex- or $G$. balcanicus-group (higher resistance against low oxygen concentrations and elevated temperatures). Subterranean members of this group have not been found so far.

8) From zoogeographical data it can be concluded that this group originates from southeastern Europe and Asia Minor. Only in Recent times $G$. roeseli has penetrated inland waters in western Europe. Members of this group are lacking in northern Europe, the British Isles, Italy and the Iberian Peninsula.
\end{abstract}

9) For all species complete lists of all studied localities are given (except for $G$. roeseli, for economical reasons), together with two maps in which the distribution is illustrated.

\section{RESUME}

1) Cette deuxième partie de la révision traite des Gammarus d'eau douce du groupe roeseli. Les membres de ce groupe artificiel sont caractérisés par la présence de carènes dorsales sur les segments du métasome.

2) Un aperçu historique est donné dès la première description de $G$. roeseli, et de la confusion taxonomique suivante. Au début de cette étude, trois espèces et au moins 15 sous-espèces étaient connues.

3) Autant que possible, le matériel-type de tous ces taxa a été réexaminé et comparé avec des centaines d'échantillons collectionnés récemment et avec du matériel provenant de tous les grands musées de l'Europe.

4) Dans cette étude les mêmes caractères morphologiques ont été utilisées que dans la révision antérieure du groupe pulex (Karaman \& Pinkster, 1977). La variabilité des divers caractères a été discutée.

5) Des descriptions complètes et beaucoup d'illustrations ont été données des mâles de toutes les espèces, accompagnées d'une clé de détermination. Si nécessaire, les caractères des femelles, lorsqu'ils sont différents, ont été figurés.

6) Il a été prouvé que $G$. triacantbus et toutes ses sousespèces doivent être considérés comme synonymes de $G$. roeseli. Quatre espèces nouvelles (G. goedmakersae, G. mladeni, G. obnixus et $G$. pavo) ont été décrites, aboutissant à un nombre total de sept espèces dans ce groupe.

7) Dans plusieurs localités des populations mixtes des membres du groupe roeseli et des groupes pulex ou balcanicus ont été trouvées. Des travaux expérimentaux ont montrés que $G$. roeseli est plus eurybionte que les membres des autres groupes (résistance plus forte aux basses concentrations d'oxygène et aux températures élevées). Nous n'avons pas encore observé des membres hypogés de ce groupe.

8) En se basant sur des données zoogéographiques, on peut conclure que ce groupe est originaire de l'Europe sud-est et 
de l'Asie Mineure. G. roeseli n'a pénétré les eaux continentales de l'Europe occidentale que pendant l'Holocène. Les membres de ce groupe sont absents de l'Europe septentrionale, des îles Brittanniques et de la péninsule Ibérique.

9) Pour toutes les espèces (abstraction faite de $G$. roeseli pour des raisons économiques) des listes complètes du matériel étudié sont données. En plus l'aire de distribution est illustrée à l'aide de deux cartes.

\section{INTRODUCTION}

In the first part of the revision of the freshwater taxa belonging to the genus Gammarus, Karaman \& Pinkster, 1977, subdivided them into three artificial groups, viz. the $G$. pulex-group, the $G$. balcanicus-group, and the $G$. roeseli-group. This subdivision was merely an artificial one, based on morphological characters only.

The members of the Gammarus roeseli-group differ from those of the other two groups in the presence of a middorsal process (carina) on each of the three metasome segments. The setation of the pereiopods 3 and 4 as well as of the uropod 3 can be long (as in the G. pulex-group) or short (as in the $G$. balcanicus-group).

The first description of a member of this group was given by Rösel von Rosenhof in 1755. Although Rösel gave a very detailed and well-illustrated description of his Squilla fluviatilis, it was in later years often confounded with the species now known as Gammarus pulex. Although the original description of the latter by Linnaeus, 1758 (as Cancer pulex) was not very detailed, it is nevertheless very clear that it was a completely different species without the dorsal carinae so clearly described by Rösel for Squilla fluviatilis. Nevertheless later authors identified their keeled gammarids as Gammarus pulex until Gervais, 1835, made it clear that there existed at least two different species: a keeled one which he called Gammarus Roeselii and a species without dorsal carinae, called Gammarus pulex. It lasted until 1905 before another keeled, closely related species was described.

When the present study was started only three species were known to belong to this group, viz. G. roeseli Gervais, 1835, G. triacantbus (Schäferna, 1922) and $G$. argaeus Vávra, 1905, but at least 15 subspecies were attributed to them. Most of

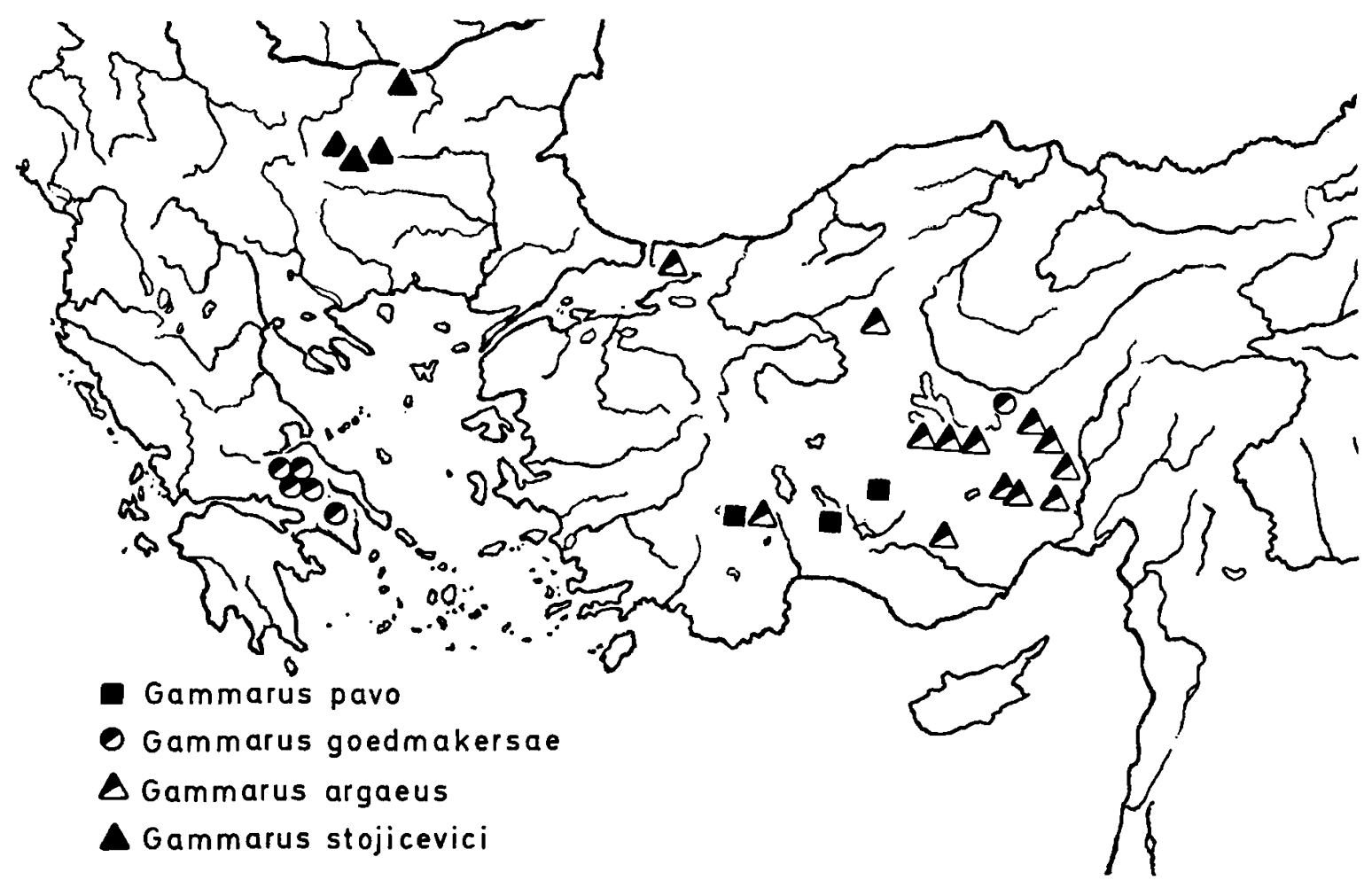

Map I. The distribution of four species of the Gammarus roeseli-group in southeastern Europe and Asia Minor. 
these subspecies were poorly described, often defined on basis of one or two characters only, which we now know to be quite variable.

Therefore it was thought wise to re-examine the type material of all known taxa. Likewise we studied the material present in all major museums and private collections in Europe, as well as a rich material collected by the second author. It became clear that this group of species has its main distribution area in southeastern Europe and Asia Minor. Six out of seven species are confined to this part of the world and only one species, $G$. roeseli, has a much wider distribution reaching from the eastern parts of Turkey to the borders of the Atlantic.

In the present paper complete descriptions of all members of the $G$. roeseli-group and a key for their identification are given. In doing so, we used the same taxonomic characters and terminology as we used previously in the revision of the $G$. pulexgroup (Karaman \& Pinkster, 1977). The distribution of the various species is discussed and illustrated in two maps, and where possible notes are given on the ecological range of the different species.

\section{ACKNOWLEDGEMENTS AND RESPONSABILITIES}

The authors are indebted to Dr. Sandro Ruffo and Dr. G. Osella of the Museo civico di Storia naturale, Verona, Italy; to Dr. G. Hartman and Dr. C. Kosswig of the Zoolog. Museum und Institut of the University of Hamburg, G.F.R.; to Dr. L. B. Holthuis of the Rijksmuseum van Natuurlijke Historie, Leiden, the Netherlands; to Dr. J. Forest of the Muséum national d'Histoire naturelle, Paris, France, for the loan of material studied in this work.

Special thanks are due to Dr. Mladen Karaman of the University of Priština, Yugoslavia, for his help in obtaining material from some museums; to Mrs. I. Pinkster-de Graaf, Drs. Annemarie Goedmakers, Drs. J. Dieleman, and Mr. J. van Veen for their assistance to the second author during his fieldwork in many parts of the area studied.

Although the present paper is, we hope, a unity, each of the authors took special care for certain sections, which were discussed afterwards with his co-author. Therefore, both authors share the full responsability for the total work.

\section{ABBREVIATIONS USED}

Z.M.A. = Zoölogisch Museum Amsterdam, the Netherlands.

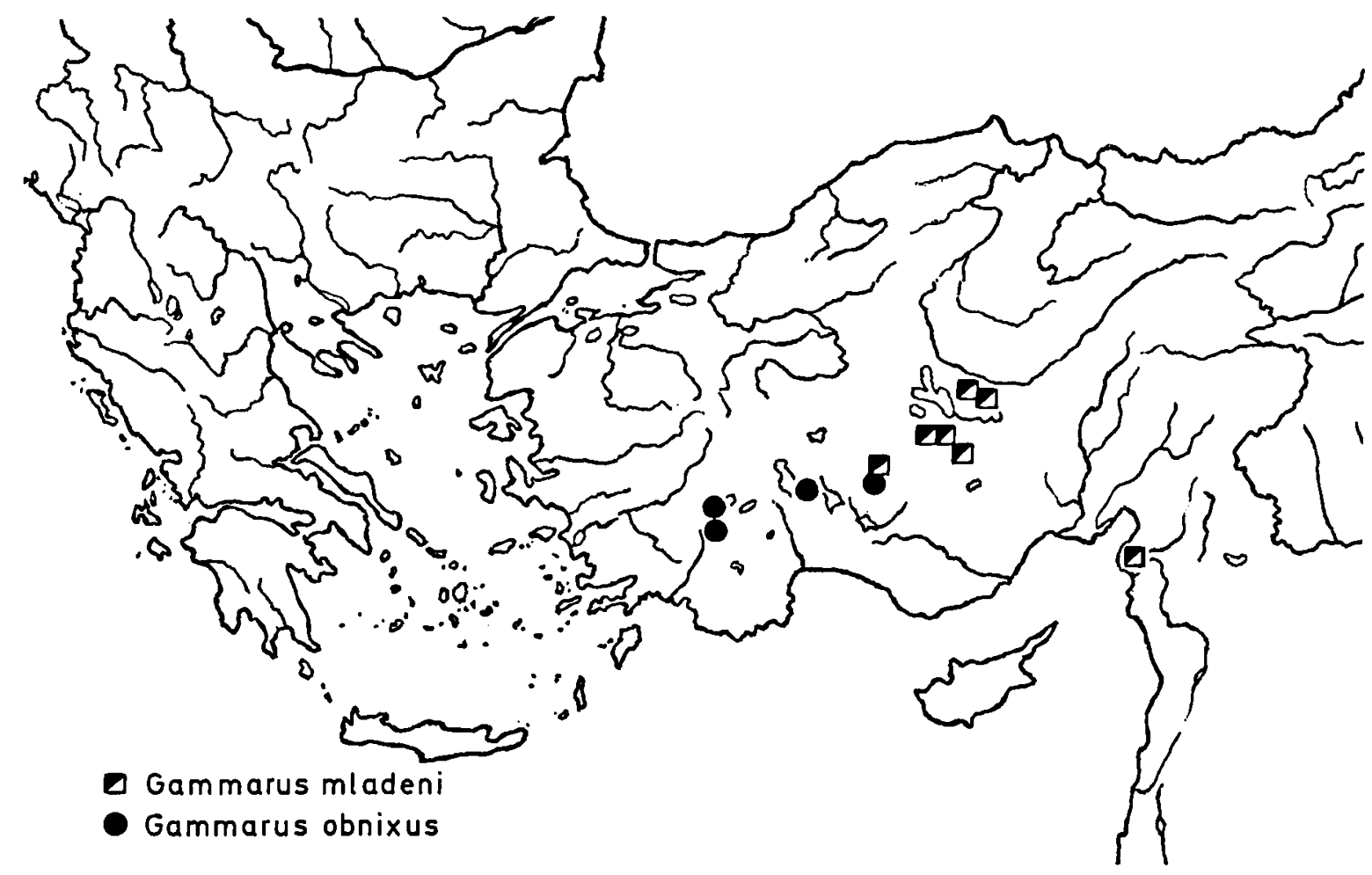

Map II. The distribution of two species of the Gammarus roeseli-group in Asia Minor. 
K.C. = Collection of S. \& G. Karaman, Titograd, Yugoslavia.

Z.M.H. = Zoologisches Museum und Institut, Hamburg, G.F.R.

M.N.H.N. = Muséum national d'Histoire naturelle, Paris, France.

M.C.S.N. = Museo civico di Storia naturale, Verona, Italy.

\section{TAXONOMIC CHARACTERS USED IN THIS} STUDY

The following taxonomic characters were used in the present study:

(1) Body length (viz. the distance from the tip of the rostrum to the tip of the telson).

(2) The dorsal armature of meta- and urosome, including the shape of the dorsal processes.

(3) The shape and size of the eyes.

(4) The shape of the cephalic lobes.

(5) The setosity of the peduncular and flagellar segments of antennae 1 and 2.

(6) The armature of the mouth parts. Since the structure of the mouth parts, except for the mandibular palp, is similar in all species within this group and identical to those figured for the $G$. pulex-group (Karaman \& Pinkster, 1977, fig. 5), the structure of the mandibular palp will be described only.

(7) The shape of the coxal plates 1 to 4 .

(8) The shape and armature of gnathopods 1 and 2 with special emphasis on the structure of the propodus.

(9) The shape and armature of pereiopods 3 to 7 , especially the length of the setation in $\mathrm{P} 3$ and P4, the presence of setae on the anterior margins of P5 to P7 and the presence of setae on the interior surface of the basal segment of P5 to P7.

(10) The number of retinacular hooks on the pleopods (since this number is two in all species studied it will not be mentioned separately in the descriptions of the species).

(11) The shape and armature of the epimeral plates.

(12) The shape and armature of uropod 3.

(13) The shape and armature of the telson lobes.

(14) Sexual dimorphism.

(15) Colour of live specimens.

All these characters will be described for the nominal form of this group, $G$. roeseli. If no details of certain characters are provided for other species, these characters can be assumed to be identical to those described for $G$. roeseli.

\section{SEXUAL DIMORPHISM}

A marked sexual dimorphism can be found in all species of the $G$. roeseli-group, even more pronounced than in most species of the $G$. pulexgroup. Females always differ from males in the following characters:

(1) Smaller body size.

(2) Relatively shorter antennae, pereiopods and uropod 3.

(3) A distinctly wider basal segment in pereiopods 5 to 7.

(4) A more slender antenna 2, always without calceoli. The setation of the peduncle segments is usually somewhat longer than in males. In $G$. roeseli however, it is considerably shorter and less densely implanted.

(5) A smaller propodus in gnathopods 1 and 2, the total number of spines being reduced; medial palmar spines are always absent.

(6) Presence of oöstegites on the ventral surface of thoracal somites 2 to 5 .

(7) Absence of a copulatory process on the ventral surface of the seventh thoracal somite.

Considerable sexual dimorphism can be present in:

(8) The abundance and length of the setation of pereiopods 3 and 4 . In females of some species this setation is shorter and less developed ( $G$. roeseli) in others $(G$. stojicevici) it is much longer and more densely implanted.

(9) The setation along the anterior margins of P5 to P7 is usually longer than in males. In some species (e.g. G. argaeus, G. stojicevici) this setation can be completely absent in males but well developed in females.

(10) The setation of uropod 3 is usually less developed than in males. In $G$. argaeus, however, the setation in the female is much longer than in the male. 
The differences mentioned sub 8 to 10 are usually greater than in the $G$. pulex-group. Moreover, unlike the pulex-group, they do not show a regular pattern.

\section{VARIABILITY OF CHARACTERS}

Each of the seven species in which the present group is subdivided, is quite variable in some characters, but not in others. Moreover, and this is one of the greatest difficulties, the characters may change in the course of the development and growth.

The most characteristic features are found in the setation of the antennae, the pereiopods and $3 \mathrm{rd}$ uropod, and the armature of metasome and urosome. As we already know from other groups (Pinkster, 1973; Karaman \& Pinkster, 1977) both number and the length of setae (and spines) increase with age and become fully characteristic only when the animal is sexually mature. Juveniles are often hard to distinguish. In this light it is important to know (and record when collecting a sample) if precopulations (sexually mature specimens) are present in a sample.

Therefore, all our remarks concerning specific characters and their variability are valid for adults only.

A. Stable characters proved to be:

(1) The structure of the mandibular palp.

(2) The shape and armature of antenna 1.

(3) The shape and armature of flagellum and peduncle of antenna 2.

(4) The presence of a medial palmar spine in gnathopods 1 and 2.

(5) The length of the setae on the posterior margin of pereiopods 3 and 4.

(6) The shape and armature of pereiopods 5 to 7 , especially the presence or absence of setae along the anterior margins.

(7) The ratio endopodite versus exopodite of uropod 3 and the nature of the setation along the outer margin of the exopodite.

(8) The presence of setae on the dorsal surface of metasome segments 1 to 3 .

(9) The shape of the epimeral plates (not their armature).
B. Variable characters proved to be:

(1) The number of segments in the flagellum of antennae 1 and 2.

(2) The length of the dorsal processes on metasome segments 1 to 3 .

(3) The dorsal armature of the urosome segments.

(4) The nature of the armature along the inferior margin of metasome segments 2 and 3 (setae and/or spines).

(5) The setation of gnathopods 1 and 2 and the telson.

Some characters which are stable in one species can be variable in other species, like the presence or absence of calceoli (stable in G. mladeni, $G$. goedmakersae and $G$. stojicevici, but instable in $G$. argaeus); the presence or absence of setae on the interior surface of P5 to P7 (stable in most species, except in $G$. roeseli).

KEY FOR THE IDENTIFICATION OF THE SPECIES OF THE GAMMARUS ROESELI-GROUP (BASED ON ADULT MALES ONLY)

1a) Anterior margin of segments 3 to 6 of pereiopods 5 to 7 bearing spines only . . . . . . . . . . . 2

b) Anterior margin of segments 3 to 6 of pereiopods 5 to 7 bearing spines intermixed with long setae. . . . 5

2a) Pereiopods 3 and 4 densely set with long setae along the posterior margin. Outer margin of exopodite of uropod 3 densely set with long setae. . . . . .

. . . . . . . . . . G. goedmakersae n. sp.

b) Pereiopods 3 and 4 poorly setose, bearing short setae along the posterior margin. Outer margin of exopodite of uropod 3 poorly armed with short setae. . . . 3

3a) Basal segment of pereiopods 6 and 7 without setae on inner surface. Endopodite of uropod 3 less than $3 / 5$ of exopodite . . . . . . . . . G. obnixus n. sp.

b) Basal segment of pereiopods 6 and 7 with setae on inner surface. Endopodite of uropod 3 at least $3 / 4$ of exopodite . . . . . . . . . . . . . . . 4

4a) Epimeres 2 and 3 very sharply pointed. Coxal plates 3 and 4 with straight inferior margin, inferior corners almost rectangular . . G. stojicevici (S. Karaman, 1929)

b) Epimeres 2 and 3 moderately pointed. Coxal plates 3 and 4 with convex inferior margin, inferior corners rounded . . . . . . . G. argaeus Vávra, 1905

5a) Peduncle of A2 poorly (sometimes moderately) setose, calceoli always present. Epimeres sharply pointed. Metasome segments 1 to 3 with setae on dorsal surface. .

$\cdot \dot{\cdot} \cdot \cdot \cdot \cdot \cdot \cdot \cdot \cdot \cdot G$. mladeni n. sp.

b) Peduncle of A2 densely setose, calceoli always absent. Epimeres rectangular to moderately pointed. Metasome segments without setae on dorsal surface . . . . 6

6a) Endopodite of uropod 3 almost as long as exopodite. Flagellum of A2 very slender, with short or moderately long setae. . . . . . . G. pavo n. sp.

b) Endopodite of uropod 3 at most $3 / 4$ of exopodite. Fla- 
gellum of A2 stout, slightly inflated, with very long setae . . . . . . . G. roeseli Gervais, 1835

\section{DESCRIPTIVE PART}

Gammarus roeseli Gervais, 1835. Figs. 1-3.

Principal refs. - Squilla (Astacus) fluviatilis Rösel, 1755: 351-357, pl. LXII figs. 1-7.

Gammarus Roeselii Gervais, 1835: 127-128; Hartwig, 1899: 36.

Gammarus Röseli; Heller, 1865: 983.

Gammarus roeseli; Roux, 1969: 123-127; Kallnbach \& Meijering, 1970: 51-59; Meijering, 1971: 575-608; Vobis, 1973: 495.508 .

Gammarus roeselii; G. Karaman, 1974: 12.

Carinogammarus roeselii; S. Karaman, 1931: 57; Schäferna, 1922: 36-40, figs. 16-17; Heinze, 1932: 398-440; Berner, 1972: 97.

Carinogammarus roeseli; Stebbing, 1906: 506; Hinz, 1975a: 109; 1975 b: 28.

Carinogammarus Roeseli; Chevreux \& Fage, 1925: 260, fig. 270; Wagler, 1937: 211.

Carinogammarus roeselii meridionalis S. Karaman, 1929: 89; 1931: 56; 1935: 128.

Carinogammarus (Rivulogammarus) roeselii; Vornatscher, 1965: 1.

Gammarus (Rivulogammarus) roeselii; Schellenberg, 1937: 511-513; 1942: 33-34, fig. 17; 1943: 99-100, fig. 2; Pacaud, 1945: 1-2; 1952: 95-111; Straškraba, 1953: 214-215; 1958: 200; 1959: 162-163; Wautier \& Roux, 1959: 118-119.

Gammarus (Carinogammarus) roeselii; Hoffmann, 1963: 9395, figs. 26-28.

Rivulogammarus roeselii; Barnard, 1958: 73; Straškraba, 1967: 208.

Rivulogammarus roeseli; Besch, 1968: 27-33.

Gammarus tetracantbus Garbini, 1902: 153.

Carinogammarus triacanthus Schäferna, 1922: 37-40, figs. 14-15; 1926: 12; S. Karaman, 1929: 89, figs. 4a, 5a; 1931: 56. Carinogammarus vardarensis S. Karaman, 1931: 57.

Carinogammarus vardarensis vardarensis S. Karaman, 1929: 90, figs. 4b, 5b, 6d; 1931: 56 .

Carinogammarus vardarensis semiarmatus S. Karaman, 1929: 91, fig. 61; 1931: 56.

Gammarus triacanthus triacanthus; G. Karaman, 1974: 13. Gammarus triacanthus prespensis; G. Karaman, 1974: 13. Gammarus triacanthus semiarmatus; G. Kataman, 1974: 13. Gammarus triacanthus strumicae; G. Karaman, 1974: 13. Rivulogammarus triacantbus; Cărăuşu, Dobreanu \& Manolache, 1955: 102-105, figs. 67-70.

Rivulogammarus (Fluviogammarus) roeselii S. \& G. Karaman, 1959: 184-207, figs. 4, 7, 11, 16, 26, 35 and 44.

Rivulogammarus (Fluviogammarus) triacantbus triacantbus S. \& G. Karaman, 1959: 184-207, figs. 5, 8, 12, 17, 29, 32 and 45 .

Rivulogammarus (Fluviogammarus) triacantbus f. montenegrinus S. \& G. Karaman, 1959: 186-206, fig. 27.

Rivulogammarus (Fluviogammarus) triacanthus prespensis S. \& G. Karaman, 1959: 186-206, figs. 6, 18, 30, 37 and 46. Rivulogammarus (Fluviogammarus) triacanthus f. vardarensis S. \& G. Karaman, 1959: 186-206, figs. 9, 13, 20, 33 and 38. Rivulogammarus (Fluviogammarus) triacantbus semiarmatus S. \& G. Karaman, 1959: 186-206, figs. 1, 21, 24, 28 and 52.
Rivulogammarus (Fluviogammarus) triacantbus nisiae S. \& G. Karaman, 1959: 186-206, figs. 22, 34 and 49.

Rivulogammarus (Fluviogammarus) triacanthus strumicae S. \& G. Karaman, 1959: 186-206, figs. 47-54.

Rivulogammarus (Fluviogammarus) triacantbus graecus S. \& G. Karaman, 1959: 186-206, figs. 2, 23, 31, 39 and 48. Gammarus pulex; Latreille, 1808: 58; Koch (in Panzer), 1836: 21.

Gammarellus pulex; Herbst, 1796: 132.

Gammarus fluviatilis; Hösius, 1850: 233.

Diagnosis. - A large species making a robust impression (fig. 1A), with 3 or 4 dorsal processes. Antenna 2 is moderately slender, densely setose. Pereiopods 3 and 4 with numerous long setae. Pereiopods 5 to 7 with spines and setae along the anterior margin of segments 3 to 6 .

Description. - Male: Maximum length observed $22 \mathrm{~mm}$. Metasome segments 1 to 3 (and in most western European samples also mesosome segment 7) are provided with a strong dorsomedian process and a few setae along the posterior margin of each segment. Urosome segments 1 to 3 are always more or less elevated, laterally compressed. In some populations urosome segment 1 has a distinct excavation ("saddle"). The dorsal armature consists of a mid-dorsal group of elements and a lateral group on each side. These groups are usually a mixture of spines and setae which can be replaced by each other. Sometimes the lateral groups can be absent in urosome segment 1 and/or 3 (figs. 1A, $2 \mathrm{G}$ and $2 \mathrm{H}$ ).

The lateral cephalic lobes are variable, from rounded to almost quadrangular, the eyes are ovoid to slightly reniform, as long as or slightly longer than the diameter of the peduncle of antenna 1 (fig. 1A, B).

The first antenna (fig. 1C) is almost half as long as the body of the animal. The third peduncle segment is about half as long as each of the other two. The number of segments in the main and accessory flagella is largely variable, 25 to 45 and 2 to 5 , respectively. The armature of both peduncle and flagella is poor.

The second antenna (figs. 1D, 3A) is relatively slender. The gland cone usually reaches the distal end of the third peduncle segment. Peduncle segment $S$ is somewhat longer than segment 4 . Both are set with groups of setae implanted in three 


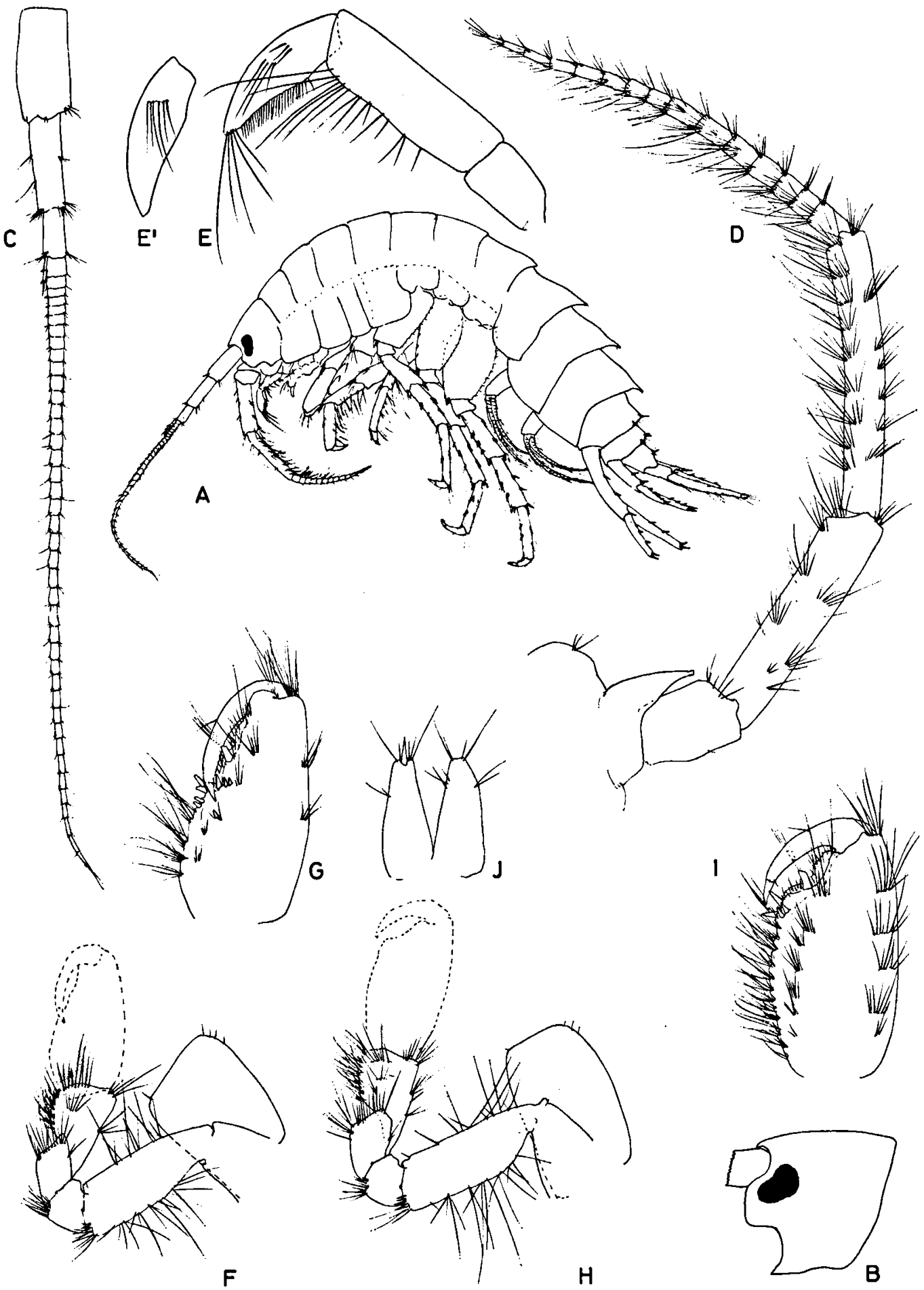

Fig. 1. A-J, Gammarus roeseli Gervais, 1835 , ô, $22 \mathrm{~mm}$, from the river Yonne, France, dépt. Nièvre. A, habitus; B, head; C, irst antenna; $\mathrm{U}$, second antenna; E, mandibular palp (outer side); $E^{\prime}$, third segment of mandibular palp (inner side); $F$, first gnathopod; G, propodus of first gnathopod; H, second gnathopod; I, propodus of second gnathopod; J, telson. 


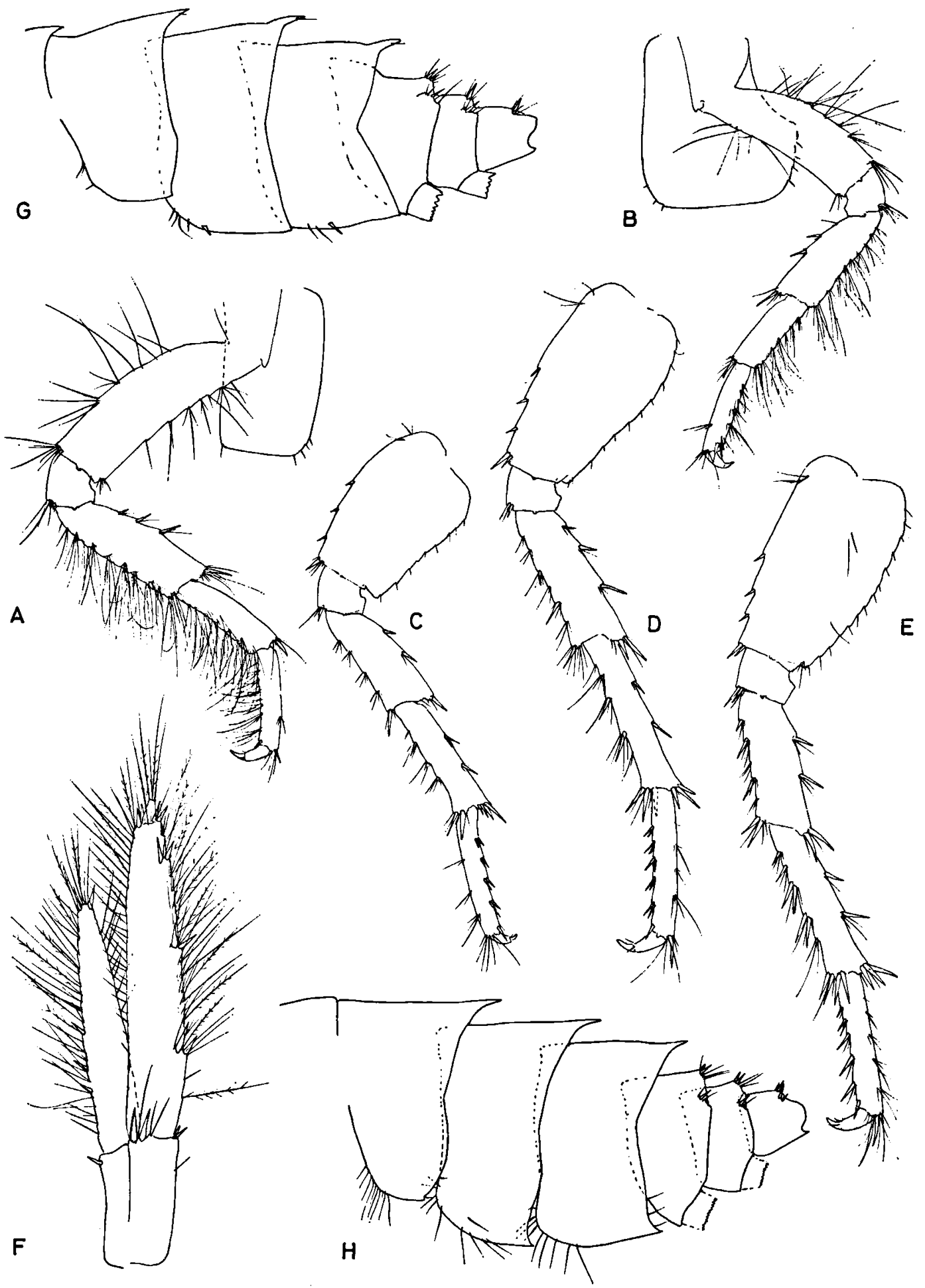

Fig. 2. A-G, Gammarus roeseli Gervais, 1835 , ô, $22 \mathrm{~mm}$, from the river Yonne, France, dépt. Nièvre. A, third pereiopod; B, fourth pereiopod; C, fifth pereiopod; D, sixth pereiopod; E, seventh pereiopod; F, third uropod; G, meta- and urosome. $\mathrm{H}$, do., of, $14 \mathrm{~mm}$, from Lake Skadar, Yugoslavia, meta- and urosome. 
longitudinal rows. The length of these setae gradually increases towards the distal end of the peduncle, from as long as to 1.5 or 2 times as long as the diameter of the segments on which they are implanted. The 12 to 16 flagellar segments are slender, or slightly swollen, always set with tufts of setae; these setae are up to three times as long as the segments on which they are implanted. Calceoli have never been found.

The second segment of the mandibular palp (fig. $1 \mathrm{E}, \mathrm{E}^{\prime}$ ) is armed with 2 or 3 setae in its proximal part and 11 to 14 setae in its distal part. The third segment has 25 to $30 \mathrm{D}$-setae, 4 or 5 E-setae, one group of A-setae and 1 or 2 groups of B-setae.

Gnathopods 1 and 2 (fig. $1 \mathrm{~F}, \mathrm{H}$ ) are moderately setose, bearing straight setae only. The propodus of the first gnathopod is elongate, twice as long as wide, armed with an obtuse medial palmar spine, some palmar angle spines and several spines along the posterior margin and the inner surface. The dactylus is slender (fig. 1G). The propodus of the second gnathopod is also elongate. The strong obtuse medial palmar spine is separated from the palmar angle group of spines by a wide gap. Many groups of straight setae are implanted on the inner surface of the propodus (fig. 1I).

Segments 4 to 6 of pereiopod 3 are armed with long, often curled, setae varying in length from 1.5 to 3 times as long as the diameter of the segments on which they are implanted. The dactylus is rather short and stout (fig. 2A).

The fourth pereiopod (fig. 2B) resembles the third one, although the setation is less dense and a little shorter. The inferior corners of coxal plates 1 to 4 vary from almost rectangular to rounded.

The fifth pereiopod (fig. 2C) has a subrectangular basis with a more or less backward protruding lobe near its distal end. In P6 and P7 (figs. 2D-E and $3 \mathrm{~B}$ ) the aspect of the basis gradually changes into a more elongate one. In P7 some setae may be implanted on the posterointerior part of the basis. The armature of segments 3 to 6 of P5 to P7 consists of a varying number of strong spines and (often longer) setae in between them. The dactyli are always short and stout. In all pereiopods the relative length of the segments increases with age.
Uropod 3 is moderately long (figs. $2 \mathrm{~F}$ and $3 \mathrm{C}$ ), its inner ramus attains about $3 / 4$ of the length of the outer ramus. The greater part of the setae implanted along the inner and outer margin of both endo- and exopodite are plumose. The density of the setation and spinulation along the outer margin of the exopodite is largely variable throughout the distribution area of the species.

The posteroinferior corner of the first epimeral plate varies from almost round to rectangular (fig. $2 \mathrm{G}, \mathrm{H})$. The plate is set with a variable number of setae in the anteroinferior part. In the second and third epimeres, the posteroinferior corners vary from almost rectangular to slightly pointed. The armature of the inferior margins in some populations exclusively consists of a number of long setae (fig. $2 \mathrm{H}$ ), in others of (a) spine(s) and some short setae (fig. 2G).

The telson lobes (fig. 1J) are elongate, more than twice as long as wide. The armature is variable, usually consisting of a terminal group of elements (always present) and one or more lateral and/or dorsal groups of elements. In these groups, which are usually a mixture of setae and spines and can be mutually replaced by each other, the setae are generally much longer than the spines. Female: Smaller than the male. As in other groups of gammarids a marked sexual dimorphism exists which is visible in almost every appendage. The main differences are: (1) The setation of both peduncle and flagellar segments of A2 is less developed (fig. 3E). (2) The propodus of P1 and $\mathrm{P} 2$ is relatively smaller, never armed with a medial palmar spine (fig. $3 \mathrm{~F}$ ). (3) The setation of pereiopods 3 to 7 is less dense, usually shorter (fig. 3D, G-J). (4) The presence of oöstegytes (brood-plates) on pereiopods 2 to 5 . The shape of these oöstegytes is age dependent. In adult females they are densely setose, about twice as long as wide (fig. $3 \mathrm{H}$ ). (5) The absence of plumose setae on the outer margin of the exopodite in uropod 3 (fig. $3 \mathrm{~K}$ ).

The colour of live specimens varies from green or yellow in some localities to brown or grey in others. Often, some red dots are present on the epimeral plates.

Variability. - Apart from the variability pattern 

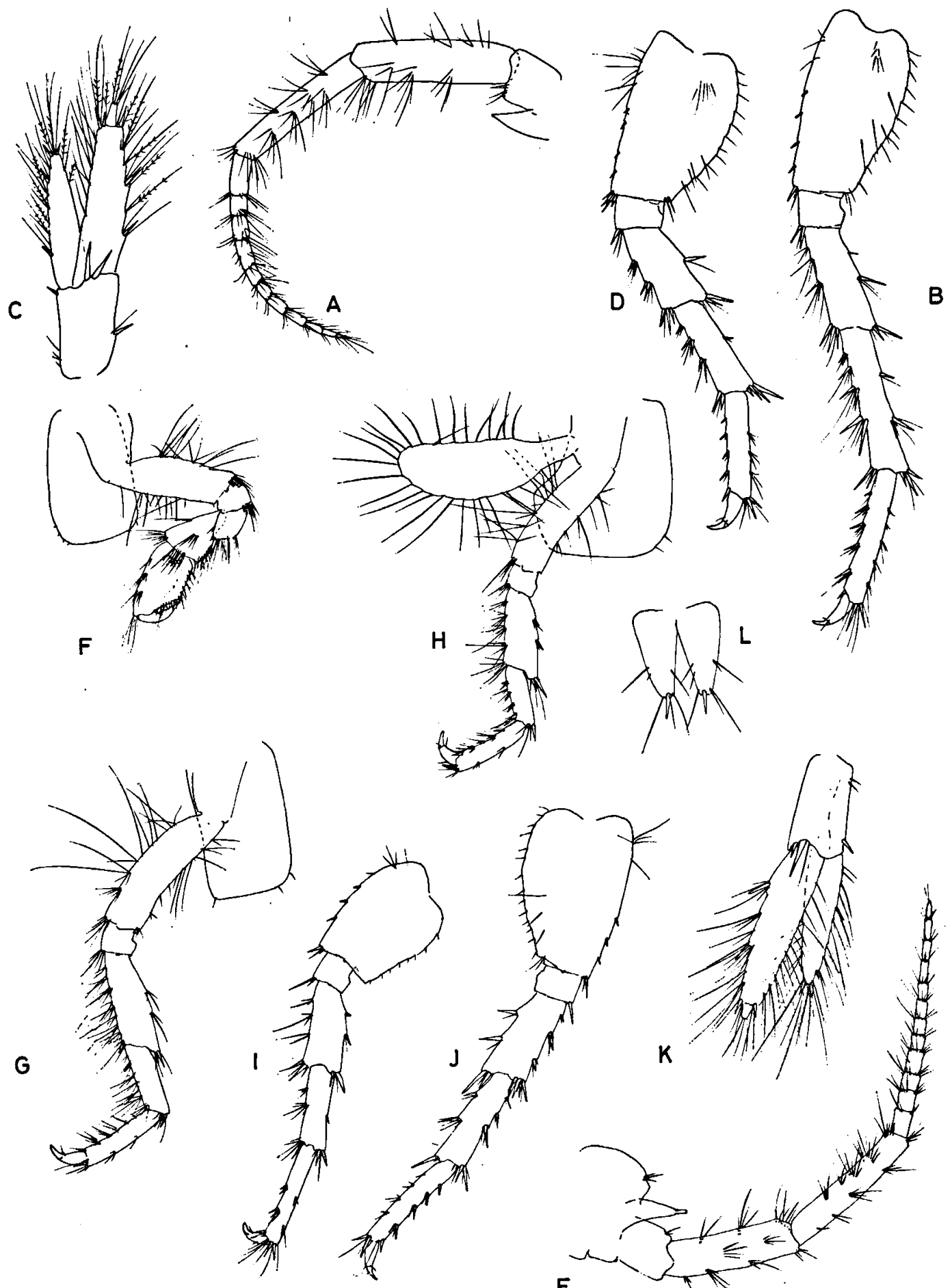

$\mathrm{E}$

Fig. 3. A-C, Gammarus roeseli Gervais, 1835, o, $14 \mathrm{~mm}$, from Lake Skadar, Yugoslavia. A, second antenna; B, seventh pereiopod; C, third uropod.

D, do., $\&, 11 \mathrm{~mm}$, from Lake Skadar, Yugoslavia, seventh pereiopod.

E-L, do., \&, $14 \mathrm{~mm}$, from the river Yonne, France, dépt. Nièvre. E, second antenna; F, first gnathopod; G, third pereiopod; $H$, fourth pereiopod; I, fifth pereiopod; J, seventh pereiopod; $K$, third uropod; $L$, telson. 
discussed in the general section on variability, this species shows considerable variability in the number of dorsal processes (see also under "remarks and affinities"). Most populations in western Europe have four dorsal processes, viz. one on the last mesosome segment and one on each of the three metasome segments. In southeastern Europe most populations have dorsal processes on the three metasome segments only. In the southern part of Yugoslavia and in Greece the three- and fourcarinate forms can be found together in the same locality. A same type of "clinal" variation can be found in the presence or absence of setae on the interior surface of the basal segment of $\mathrm{P} 6$ and P7. In populations from southeastern Europe these setae are (usually) present, whereas they are (usually) absent in populations from western Europe. Nevertheless, in nearly every population we can find exceptions to the general pattern.

Material examined. - More than 500 samples from all over the distribution area. To economize space the localities are not mentioned separately.

Loc. typ. - Gervais, 1835, did neither indicate types nor a type locality. For the stability of nomenclature, however, it is of the utmost importance that a neotype should be selected. Since Gervais' study was based upon material from the surroundings of Paris, we thought it wise to select a neotype from this area. So the neotype locality is: the river Yonne, at Coulanges-sur-Yonne (near Vézelay), dépt. Nièvre, France. The $\hat{\delta}$ neotype and many other specimens from the neotype locality have been deposited in the Zoölogisch Museum Amsterdam, under cat. no. Z.M.A. Amph. 103.574 a \& b.

Distribution. - Asia Minor (own material), Greece including the Peloponnesos (S. Karaman, 1931; S. \& G. Karaman, 1959, own material), Yugoslavia (S. Karaman, 1929, 1931, 1935; S. \& G. Karaman, 1959; G. Karaman, 1974), Bulgaria (own material), Roumania (Cărăuşu et al., 1955), Hungary (Cărăuşu et al., 1955), the lower parts of Austria (Vornatscher, 1965), Czechoslovakia (Straškraba, 1953, 1958, 1959), the plains in the northwestern parts of Poland (Jażdżewski, 1975), the plains and lower mountainous regions of Germany (both G.D.R. and G.F.R.) (Schellenberg, 1942; Kallnbach \& Meijering, 1970; Meijering, 1971; Besch, 1968), the southern and eastern parts of the Netherlands (own material), Belgium and Luxembourg (Hoffmann, 1963) and the northern and eastern parts of France (Pacaud, 1952; Roux, 1969).

This distribution pattern and the distribution of the related species within this group suggests that $G$. roeseli (and possibly the whole $G$. roeseligroup) has its evolutionary centre in southeastern Europe or Asia Minor and that its penetration in the rest of Europe is a relatively recent one. In agreement with this theory are the data given by Pacaud, 1952, Wautier \& Roux, 1959 and Roux, 1969 , showing that $G$. roeseli only recently invaded the northeastern parts of France and is still enlarging its distribution area in western and southern direction.

Remarks and affinities. - Since $G$. roeseli was the first described Gammarus species with a carinate metasome, it was chosen as the nominate species of this group. Although it is widely distributed and therefore should be a relatively well known species, there has been an enormous confusion about its identity as can be seen from the long list of synonyms. The main sources of this confusion in our opinion are (1) the often incomplete and scarcely illustrated descriptions in earlier taxonomic papers and (2) the incomplete knowledge of the variability of the various morphological characters. Schäferna, 1922, described $G$. triacanthus as a different species, an action that seemed then justified since intermediates between this form with three keeled segments and $G$. roeseli with four keeled segments were not known and since both forms were described from widely separated areas.

S. Karaman, 1929, 1931 and 1935, in exploring the freshwater fauna of Yugoslavia and Greece, found many populations differing from $G$. triacantbus as described by Schäferna in one or more characters. Since these populations were found in different stream systems, he felt justified calling them subspecies of $G$. triacantbus.

S. \& G. Karaman, 1959, in a comprehensive study of $G$. triacantbus and $G$. roeseli still considered these morphologically different forms as subspecies of $G$. triacanthus but at the same time they ascertained the existence of populations (Ohrid and Skadar lakes) in which the forms with three and four keels occur together; the term 
"hybrids" is even mentioned. In the same paper they described this phenomenon from waters in the stream system of the Danube. Nevertheless, from these observations they did not draw the conclusion that $G$. roeseli and $G$. triacanthus could possibly be mere variations of one species.

During the present study we re-examined all the material studied by S. \& G. Karaman and many samples from other parts of Europe. Special emphasis was given to the variability of the morphological characters (and the development of these characters during the various growth stages). It became clear that all forms described as subspecies of $G$. triacanthus should be considered mere varieties of one species. At the same time we found that the form with only three dorsal processes was not restricted to southeastern Europe but also could be found (although in very small numbers) in populations from the French départements Jura, Ain, Hte.-Marne, and Hte.-Saône. Precopulations between the two forms have also been found. In spite of an intensive search, stable morphological differences other than the presence of a usually small dorsal process on the last mesosome segment, could not be found between the two forms. Having considered the arguments mentioned above, we now are convinced that $G$. triacantbus and all the subspecies attributed to it are mere variations of one species: G. roeseli Gervais, 1835.

Ecology. - In western Europe, G. roeseli is an inhabitant of middle and lower reaches of streams and rivers where stream velocities are moderate and the daily and yearly temperature changes are not too strong. It is often found coexisting with G. p. pulex and/or G. fossarum. It appears to be less resistant against high stream velocities than the other two species (Meijering, 1972; Vobis, 1973 ) especially when temperatures are low. This is probably the reason why this species, in areas in which it penetrated recently (e.g. the Rhône valley in France, Roux, 1969), is confined to the lower reaches of the smaller river systems near the confluence with the main river. It does not seem able to invade the spring regions of these tributaries. Nevertheless the species is gradually enlarging its geographical range (Roux, 1969), penetrating into an area already inhabited by $G$. fossarum and G. p. pulex. This successful competition can probably be explained by its ability to withstand a higher degree of organic pollution.

In Yugoslavia it is found in all kinds of habitats like small mountain streams, large rivers and lakes (Lake Skadar, Lake Ohrid) often together with members of the Gammarus pulex- or G. balcanicusgroup. Some recent studies on the ecology of a $G$. roeseli population in Macedonia by the first author showed that $G$. roeseli is more eurybiont than species belonging to the $G$. pulex- or $G$. balcanicus-group from the same region. $G$. roeseli can bear higher water temperatures, a higher degree of organic pollution and lower oxygen saturation levels than all other species from the same water systems.

Little is known about the ecology of this species in other parts of Europe.

\section{Gammarus pavo n. sp. Figs. 4, 5A-G.}

Diagnosis. - Medium large species with three dorsal processes. Antenna 2 moderately setose; flagellum very slender, without calceoli. Pereiopods 3 to 7 densely setose. Exopodite of uropod 3 with setose outer margin. Epimeres moderately pointed.

Description. - Male: Maximum length observed $17 \mathrm{~mm}$. Metasomites 1 to 3 provided with a strong dorsomedian process, accompanied on each side by 3 to 5 setae along the posterior margin of the somites. Urosomites 1 to 3 moderately elevated, laterally slightly compressed; each somite is armed with one dorsomedian and two dorsolateral groups of elements consisting of 1 or 2 spines intermixed with 1 to 4 setae each (fig. $4 \mathrm{~N}$ ).

The lateral cephalic lobes are more or less rounded; the eyes are ovoid to slightly reniform, as long as or shorter than the diameter of the peduncle of A1 (fig. 4A).

The first antenna attains up to $3 / 5$ of the body length. Both peduncle and flagellum are poorly setose. The main and accessory flagella have 24 to 30 , and 3 to 4 segments, respectively (fig. 4B).

The second antenna is moderately setose. The gland cone reaches the distal end of the third peduncle segment; peduncle segments 4 and 5 bear 4 or 5 and 5 to 7 groups of setae at the ventral margin. These setae are usually slightly longer than 


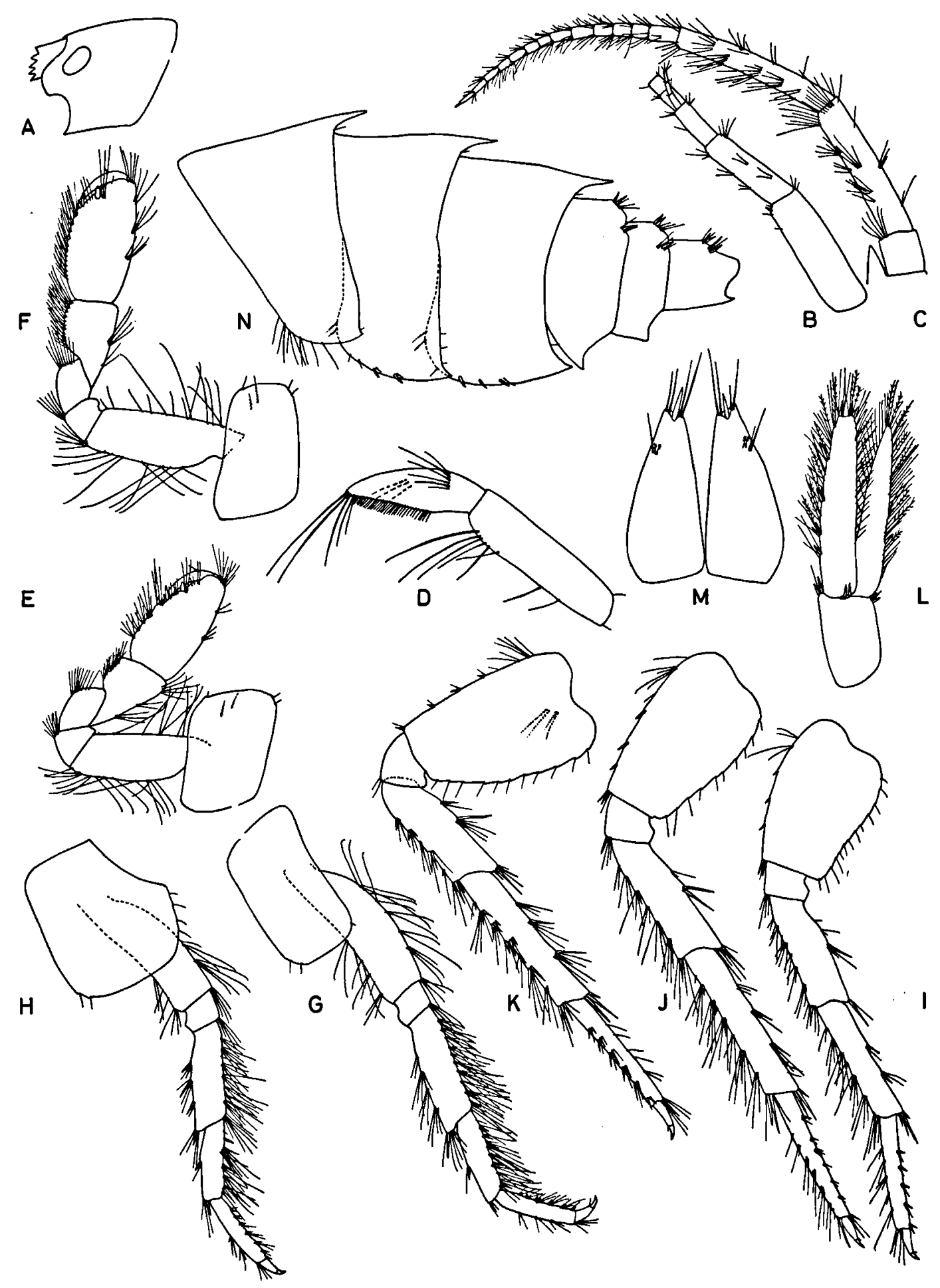

Fig. 4. A-N, Gammarus pavo n. sp., ô, $15 \mathrm{~mm}$, from stream between Lake Acigöl and Lake Burdurgöl, prov. Burdur, Turkey. A, head; B, first antenna; C, second antenna; D, mandibular palp; E, first gnathopod; F, second gnathopod; G, third pereiopod; $H$, fourth pereiopod; I, fifth pereiopod; J, sixth pereiopod; K, seventh pereiopod; L, third uropod; M, telson; N, metaand urosome. 
the diameter of the segments on which they are implanted. The up to 14-segmented flagellum is very slender, moderately setose, hardly compressed dorsoventrally. The setae on the flagellar segments are little longer than the diameter of these segments. Calceoli have not been found (fig. 4C).

The second segment of the mandibular palp has 2 or 3 setae in its proximal part and 6 to 8 setae in its distal part. Segment 3 has 26 to $30 \mathrm{D}$-setae, 4 to $6 \mathrm{E}$-setae, one group of A-setae and one group of B-setae (fig. 4D).

Gnathopods 1 and 2 are moderately setose, bearing straight setae only. Apart from the slightly shorter setation, the propodus of both gnathopods is identical to that of $G$. roeseli (fig. $4 \mathrm{E}-\mathrm{F}$ ).

Pereiopod 3 is densely setose; the posterior margin of segments 2 to 5 is provided with numerous groups of straight setae, longer than the diameter of the segments. In segment 6 these setae are little longer, accompanied by pairs of short spines. Pereiopod 4 is slightly less setose than P3 (fig. 4G-H). Coxal plates 1 to 4 have rounded inferior corners.

Segments 3 to 6 of pereiopods 5 to 7 bear groups of long setae along their anterior margins, often intermixed with one or more short spines. These setae are usually longer than the diameter of the segments. In P7 some setae may be found on the interior surface of the basis (fig. $4 \mathrm{I}-\mathrm{K}$ ).

The shape of the epimeral plates changes from rectangular in the first to moderately pointed in the third. Several short spines intermixed with some short simple setae form the armature of epimeres 2 and 3 (fig. $4 \mathrm{~N}$ ).

Uropod 3 is moderately long. Its endopodite almost reaches the distal end of the first exopodal segment. Both rami bear numerous, medium long, plumose and simple setae along the inner and outer margins. In addition, groups of spines are implanted along the outer margin of the exopodite (fig. 4L).

The telson lobes are long, more than twice as long as wide, tapering towards the distal end. They are poorly armed with a distal group of 1 to 3 spines and several setae (longer than the spines). Occasionally one or two setae can be found on the dorsal surface (fig. 4M).

Female: Except for the usual sexual dimorphism observed in all gammarids, females resemble the males in almost every character (although the setation may be slightly less dense (see fig. 5A-G).

Colour of live specimens unknown.

Variability. - Except for the armature of the epimeral plates and the telson, most characters seem to be rather stable.

Material examined. -

Turkey: Prov. Burdur, between Lake Acigöl and Lake Burdurgöl, 6/7-VII-1973, many specimens (M.C.S.N., K.C.).

- Prov. Konya, well near Lake Dinar Karakugu at Pinarbaşi, 7.V-1959, 3 specimens, accompanied by G. agrarius (G. Karaman) and G. obnixus n. sp. (Z.M.H.).

- do., Lake Dinar Karakugu at Düdenler, 7-V-1959, many specimens accompanied by $G$. obnixus n. sp. and $G$. agrarius (G. Karaman) (Z.M.H.).

Loc. typ. - Turkey, Prov. Burdur, between Lake Acigöl and Lake Burdurgöl. The ô holotype, $15 \mathrm{~mm}$, and many paratypes have been deposited in the Museo civico di Storia naturale, Verona. Several paratypes are deposited in the Karaman Collection, Titograd.

Distribution. - Central part of Asia Minor (see map I).

Remarks and affinities. - $G$. pavo differs from G. goedmakersae, G. obnixus, G. stojicevici, and $G$. argaeus in its setose anterior margins of P5 to P7. It differs from $G$. mladeni in the absence of setae on the dorsal surface of the metasome segments and its moderately pointed epimeres. It differs from $G$. roeseli in the less developed setation of the flagellum of $\mathrm{A} 2$ and the longer endopodite of uropod 3.

The name pavo (= Latin, peacock) refers to the rich setation in this species.

\section{Ecology. - Unknown.}

Gammarus goedmakersae n. sp. Figs. 5H-N, 6. Diagnosis. - Medium large species with three dorsal processes. Antenna 2 slender, with calceoli, poorly setose. Pereiopods 3 and 4 and uropod 3 densely setose. Pereiopods 5 to 7 without setae along the anterior margin. Epimeres moderately sharp.

Description. - Male: Maximum length observed $14 \mathrm{~mm}$. Mesosome and metasome without dorsal setae. Metasome segments 1 to 3 each have a 

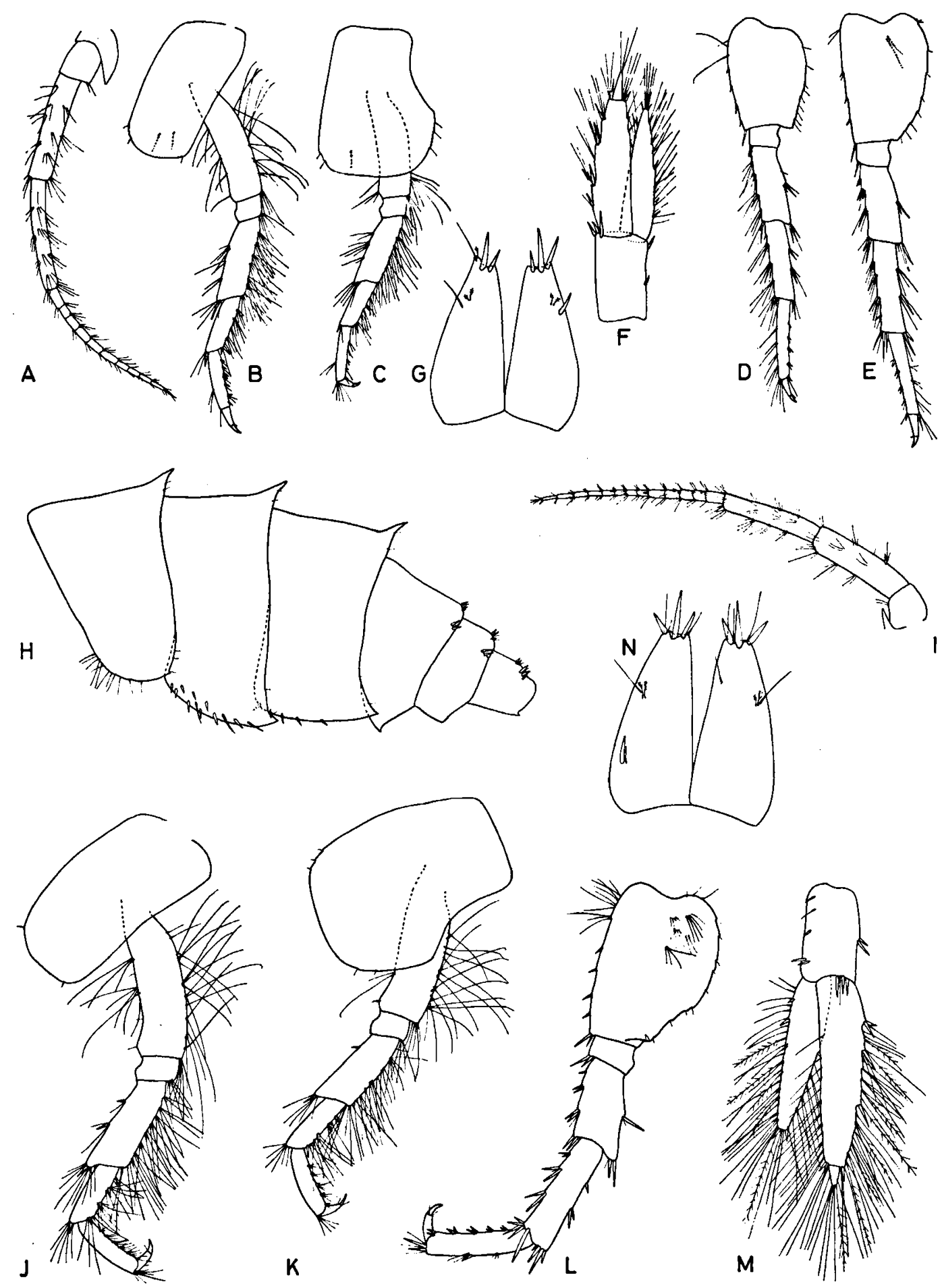

Fig. 5. A-G, Gammarus pavo n. sp., $\$, 10 \mathrm{~mm}$, from stream between Lake Acigöl and Lake Burdurgöl, prov. Burdur, Turkey. A, second antenna; B, third pereiopod; C, fourth pereiopod; D, fifth pereiopod; E, seventh pereiopod; F, third uropod; $\mathbf{G}$, telson.

H, Gammarus goedmakersae n. sp., ô, $13.8 \mathrm{~mm}$, from Karputzatan, prov. Kayseri, Turkey, meta- and urosome.

$\mathrm{I}-\mathrm{N}$, do., $\$$, $8.8 \mathrm{~mm}$. I, second antenna; J, third pereiopod; K, fourth pereiopod; L, seventh pereiopod; M, third uropod; $N$, telson. 

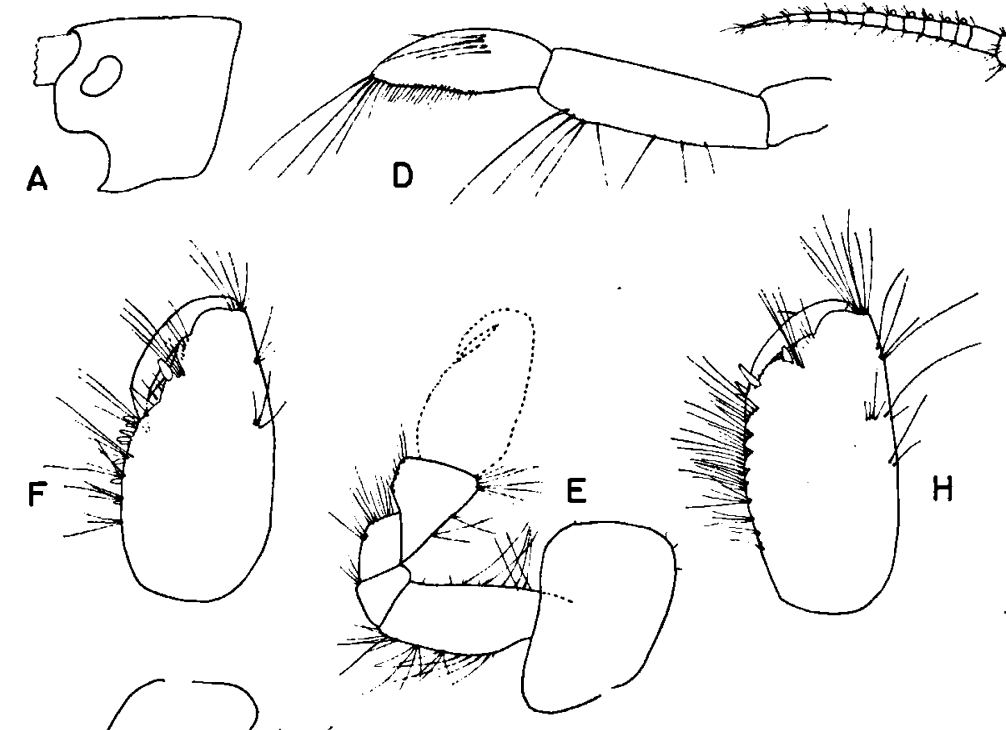

C
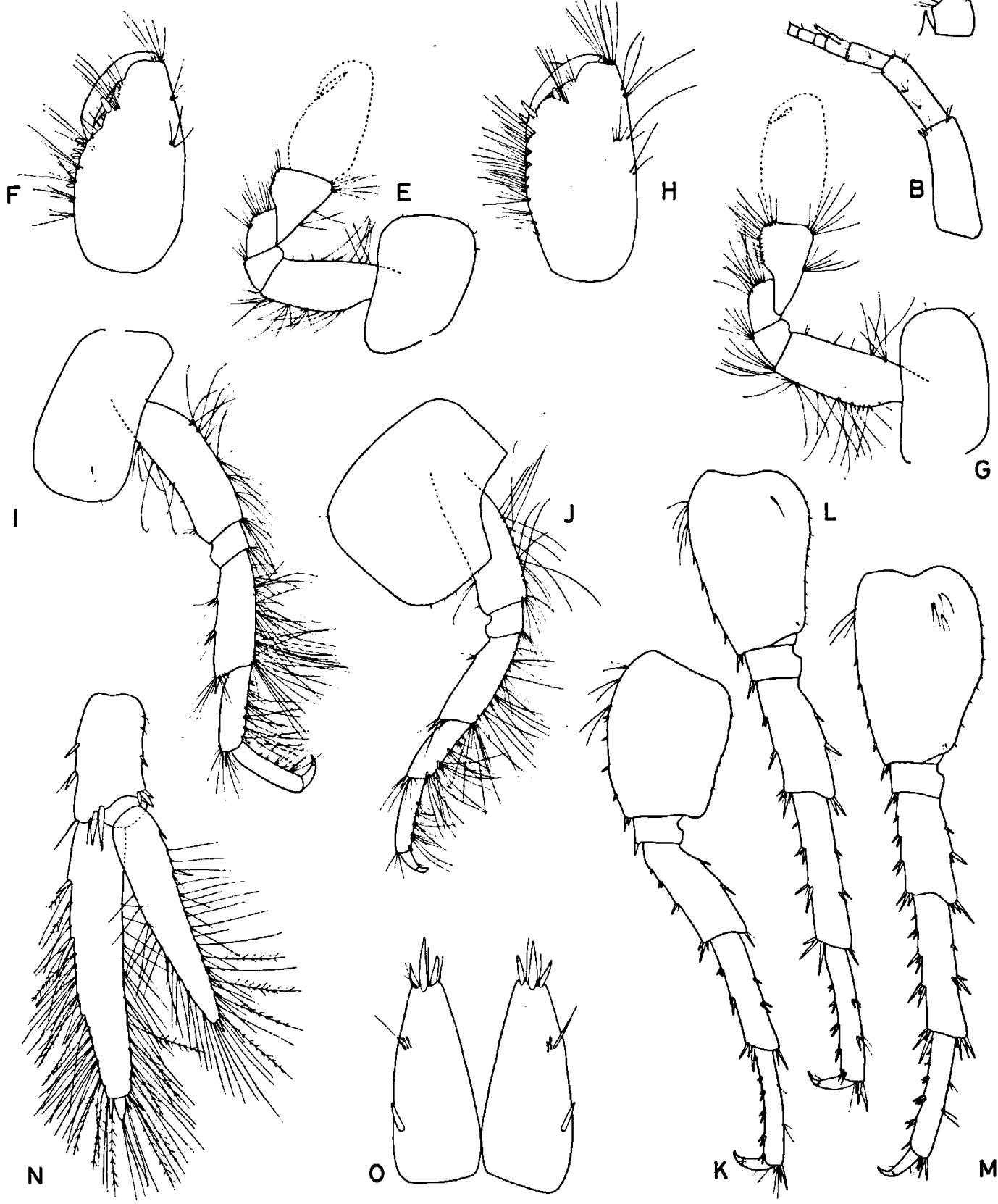

Fig. 6. A-O, Gammarus goedmakersae n. sp., ô, $13.8 \mathrm{~mm}$, from Karputzatan, prov. Kayseri, Turkey. A, head; B, first antenna; C, second antenna; D, mandibular palp; E, first gnathopod; F, propodus of first gnathopod; G, second gnathopod; $\mathrm{H}$, propodus of second gnathopod; I, third pereiopod; J, fourth pereiopod; $K$, fifth pereiopod; $L$, sixth pereiopod; $M$, seventh pereiopod; $N$, third uropod; $O$, telson. 
dorsomedian process and 4 to 6 short setae along the posterolateral margin of each segment. Urosome segments 1 to 3 are slightly elevated, laterally not or only slightly compressed. The dorsal armature of the urosome consists of one middorsal and two dorsolateral groups on each segment, consisting of 1 to 3 spines and 1 to 3 very short setae (fig. $5 \mathrm{H}$ ).

The lateral cephalic lobes have rounded to rectangular corners. The eyes are reniform, about as long as the diameter of the peduncle of $\mathrm{A} 1$ (fig. 6A).

The first antenna is poorly setose, $1 / 2$ to $3 / 5$ as long as the body. Peduncle segments 1 to 3 bear a few groups of short setae along the ventral margin. The main flagellum and accessory flagellum have 26 to 35 and 3 to 4 segments, respectively (fig. 6B).

The second antenna is slender, poorly setose. The gland cone almost reaches the end of the third peduncle segment. Peduncle segments 4 and 5 are equally long with 3 to 4 and 5 to 6 groups of very short setae along the ventral margin. The flagellum is slender, up to 14-segmented, sometimes slightly compressed dorsoventrally. Calceoli are always present (fig. $6 \mathrm{C}$ ).

The second segment of the mandibular palp bears 2 or 3 setae in its proximal part and 5 or 6 setae in its distal part. Segment 3 is armed with 23 to $25 \mathrm{D}$-setae, 4 to $6 \mathrm{E}$-setae, one group of A-setae and 1 or 2 groups of B-setae (fig. 6D).

Gnathopods 1 and 2 are moderately setose, bearing straight setae only (fig. 6E, G). The propodus in both gnathopods is armed with a medial palmar spine and 1 to 3 palmar angle spines; a variable number of smaller spines can be implanted on the interior surface and the posterior margin (especially in $\mathrm{P} 1$ ). The setation is poorly developed, though variable (fig. $6 \mathrm{~F}, \mathrm{H}$ ).

Pereiopods 3 and 4 are densely setose, the posterior margin of all segments being provided with long straight setae. These setae are always markedly longer than the diameter of the segments. P4 is slightly less setose than P3 (fig. 6I, J). Coxal plates 1 to 4 have rounded inferior corners.

Segments 3 to 6 of pereiopods 5 to 7 are armed with spines along the anterior and posterior margins; setae are practically absent. In P6 and P7 some setae may be found on the interior surface of the basis (fig. 6K-M). The dactyli in all pereiopods are moderately slender.

The posteroinferior corners of epimeral plates 1 to 3 are rectangular (in epimere 1 ) to moderately pointed (in epimere 3 ). The armature of epimere 2 usually consists of spines and some short setae, in epimere 3 of spines only (fig. $5 \mathrm{H}$ ).

The third uropod is moderately long. Its endopodite is $2 / 3$ to $3 / 4$ of the exopodite. Both rami are densely set with long, often plumose setae (fig. 6N).

The telson lobes are elongate, more than twice as long as wide, each lobe with 2 to 4 distal spines and some short setae. On the dorsal surface of the lobes one or two simple spines or setae can be implanted (fig. 60).

Female: Apart from the usual differences like the absence of calceoli and of medial palmar spines in the propodus of the gnathopods, females of this species differ from the other sex in the slightly longer setation of the peduncle of $\mathrm{A} 2$ (fig. 5I) and the presence of more setae on the inner surface of the basal segments of P6 and P7 (fig. $5 \mathrm{~L}$ ). All other characters are more or less identical to those in males (fig. 5J-K, M-N). Unlike most other species, females of G. goedmakersae have plumose setae on the outer margin of the exopodite in the third uropod.

The colour of life specimens is brown to greenish.

Variability. - Considerable variability can be observed in the height of the dorsal processes of the metasome; in the population from the type locality these are very high, in populations from the province of Fthiotis, Greece, they can be very low. The armature of the second epimeral plate in the population from the type locality consists of spines only, in populations from Greece of spines and setae. Within one population the length of the inner ramus of uropod 3 can vary from $2 / 3$ to $3 / 4$ of the outer ramus.

\footnotetext{
Material examined. -

Turkey: Prov. Kayseri, Karputzatan, 20-V-1959, 10 specimens (Z.M.H., K.C.).

Greece: Prov. Attiki, surroundings of Athens, no date, 20 specimens (M.N.H.N.).

- Prov. Fthiotis, river Sperkhión, S. of Lamia, 25-1X-1973, 17 specimens (Z.M.A.).
} 
- do., small brooklet on Bralos pass, about $30 \mathrm{~km} \mathrm{~S}$. of Lamia, 25-IX-1973, many specimens (many in precopulation) (Z.M.A.).

- Prov. Voiotia, confluent of Kifisós, $3 \mathrm{~km} \mathrm{S.} \mathrm{of} \mathrm{Station}$ Davlia, about $25 \mathrm{~km} \mathrm{N.W.} \mathrm{of} \mathrm{Levádia,} \mathrm{25-IX-1973,} \mathrm{many}$ specimens, many in precopulation (Z.M.A.).

Loc. typ. - Turkey, Prov. Kayseri, Karputzatan. The of holotype, $13.8 \mathrm{~mm}$, and 7 paratypes have been deposited in the Zoolog. Museum und Institut, Hamburg; 2 paratypes have been deposited in the Karaman Collection, Titograd, Yugoslavia.

Distribution. - So far this species is known from two disjunct areas: Asia Minor and Greece (see map I).

Remarks and affinities. - G. goedmakersae differs from $G$. mladeni, $G$. pavo and $G$. roeseli by the absence of setae on the anterior margin of P5 to $\mathrm{P} 7$. It differs from the other species in the roeseligroup by the long setation on $\mathrm{P} 3$ and $\mathrm{P} 4$ and on the outer margin of the exopodite in the third uropod.

This species is dedicated to our colleague and dear friend, Annemarie Goedmakers.

Ecology. - So far the species is only known from clear, fast running waters with a stony substrate.

Gammarus argaeus Vávra, 1905. Figs. 7, 8 M-S.

Refs. - Gammarus argaeus Vávra, 1905: 109-112, pI. III figs. 10-12; G. Karaman, 1974: 9.

Gammarus argaeus var. brachyurus Vávra, 1905: 111, pl. III fig. 13.

Carinogammarus argaeus; S. Karaman, 1931: 61.

Rivulogammarus argaeus; Straškraba, 1967: 208.

Gammarus (Fluviogammarus) argaeus; S. \& G. Karaman, 1959: 198-201.

Gammarus (Fluviogammarus) argaeus burduri S. \& G. Karaman, 1959: 200-201, figs. 15, 25, 41, 50 and 53.

Diagnosis. - Medium large species with three dorsal processes. Antenna 2 relatively short, moderately slender, poorly setose, usually with calceoli. Pereiopods 3 and 4 poorly setose. Pereiopods 5 to 7 without setae along the anterior margin of segments 3 to 6; basal segment usually with setae on the interior surface. Metasomites without dorsal setae. Exopodite of uropod 3 with poorly setose outer margin.

Description. - Male: Maximum length observed $15 \mathrm{~mm}$. Metasomites 1 to 3 are each provided with a dorsal process, which can be more or less strongly developed, and 3 to 10 setae at the posterolateral margin of each somite. Urosomites 1 to 3 slightly elevated, not compressed. The dorsal armature of the urosome consists of a mid-dorsal and two dorsolateral groups on each segment with 1 or 2 spines and 1 to 5 setae in each group (fig. 7P).

The lateral cephalic lobes are rounded; the eyes are small, ovoid, slightly shorter than the diameter of the peduncle of antenna 1 (fig. 7A).

The first antenna (fig. 7B) is half as long as the body of the animal. Both the peduncle and flagellum are poorly setose. The main and accessory flagella have 22 to 31 and 2 to 4 segments, respectively.

The second antenna is slender. The gland cone is little longer than half the third peduncle segment. Peduncle segments 4 and 5 are moderately setose with 3 to 4 and 4 to 5 groups of setae along the ventral margin. These setae are usually shorter than the diameter of the peduncle segments. The 8 to 11 flagellar segments are slender or slightly swollen, slightly dorsoventrally compressed, bearing setae as long as or slightly longer than the diameter of the segments. Calceoli are usually present (fig. 7C).

The second segment of the mandibular palp has 3 to 5 setae in its proximal part and up to 10 setae in its distal part. Segment 3 is armed with 22 to $25 \mathrm{D}$-setae, 4 to $5 \mathrm{E}$-setae, one group of A-setae and one group of B-setae (fig. 7D).

Gnathopods 1 and 2 are moderately setose (fig. $7 \mathrm{E}, \mathrm{G})$, bearing straight setae only. In both gnathopods the propodus is about twice as long as wide, provided with a medial palmar spine and 2 to 4 palmar angle spines. The setation of the propodus is poorly developed as compared to G. roeseli (fig. $7 \mathrm{~F}, \mathrm{H}$ ).

Pereiopods 3 and 4 are poorly setose (fig. 7I, J). The posterior margin of segments 3 to 5 bears small groups of short setae, usually much shorter than the diameter of the segments, in segment 5 accompanied by some groups of spines. Segment 6 bears many pairs of short spines at the posterior margin, occasionally accompanied by a short seta. $\mathrm{P} 4$ is less setose than P3. The inferior corners of coxal plates 1 to 4 are more or less rounded.

Segments 3 to 6 of pereiopods 5 to 7 are armed with spines along the anterior and posterior 


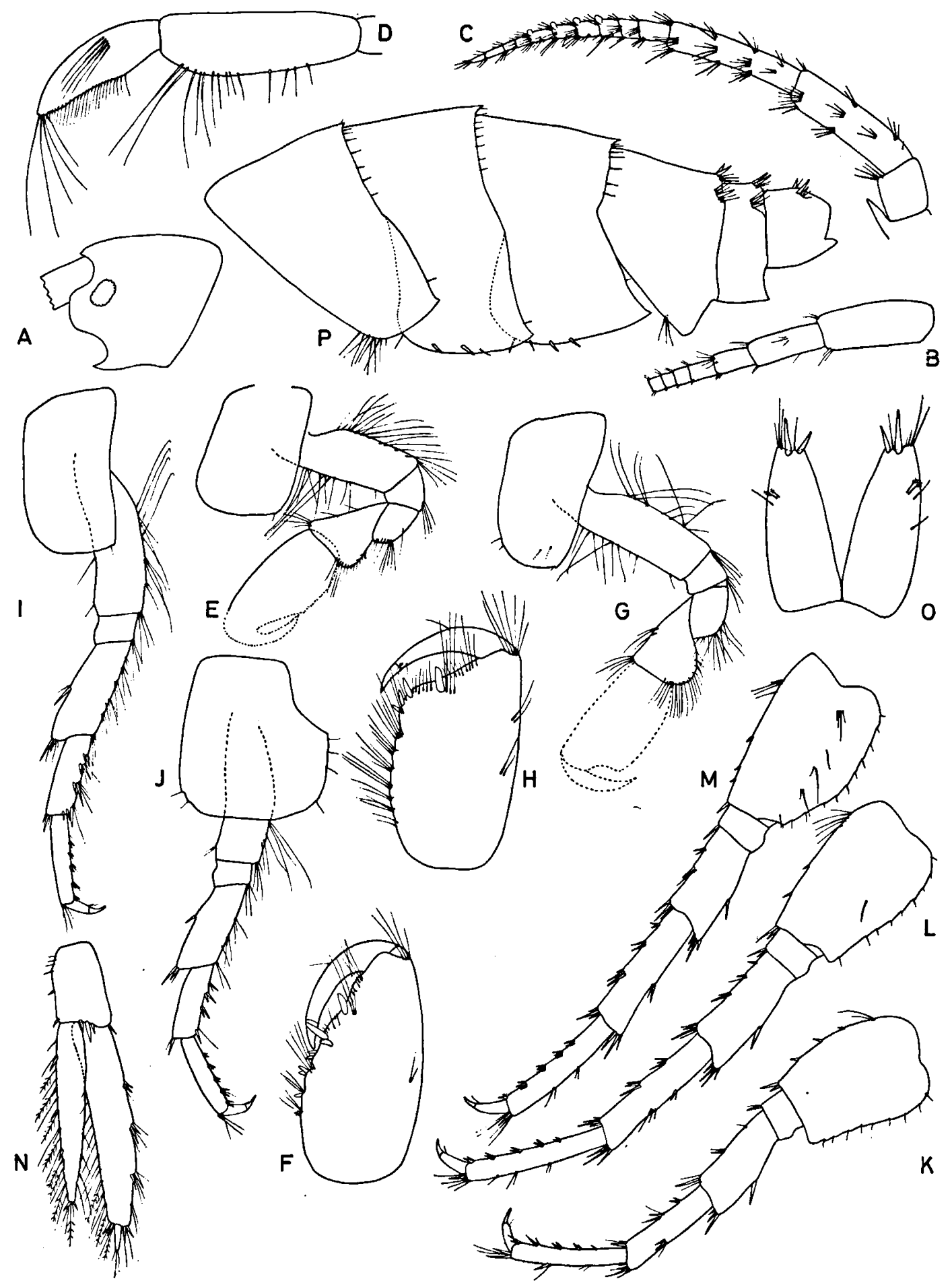

Fig. 7. A-P. Gammarus argaeus Vávra, 1905, ô, $11 \mathrm{~mm}$, from vicinity of Burdurgöl, prov. Burdur, Turkey. A, head; B, first antenna; C, second antenna; D, mandibular palp; E, first gnathopod; F, propodus of first gnathopod; G, second gnathopod; H, propodus of second gnathopod; I, third pereiopod; J, fourth pereiopod; $K$, fifth pereiopod; L, sixth pereiopod; $\mathrm{M}$, seventh pereiopod; $\mathrm{N}$, third uropod; $\mathrm{O}$, telson; $\mathrm{P}$, meta- and urosome. 
margins. Setae are almost absent. In P6 and P7 (and rarely in P5) setae are implanted on the inner surface of the basal segment (figs. 7K-M). In all pereiopods the dactyli are relatively slender.

Uropod 3 is moderately long. The inner ramus attains about $4 / 5$ to $5 / 6$ of the outer ramus. The outer margin of the exopodite is poorly armed with a few groups of spines and some simple setae. The other margins of endo- and exopodite bear simple and plumose setae (fig. $7 \mathrm{~N}$ ).

The posteroinferior corners of the epimeral plates vary from almost rectangular in the first to moderately pointed in the third. The inferior margin of epimeres 2 and 3 is armed with spines, sometimes accompanied by a single short seta (fig. 7P).

The telson lobes are elongate, more than twice as long as wide, poorly armed. Usually the armature consists of a distal group of spines and setae and one or two simple setae on the dorsal surface. The distal setae vary in length from very short to slightly longer than the spines (fig. $7 \mathrm{O}$ ).

Female: Differs from the male in the setation of many appendages, viz. (1) The longer setation on the peduncle of A2 (fig. $8 \mathrm{M}$ ); (2) the much longer and denser setation of pereiopods 3 and 4 (fig. $8 \mathrm{~N}, \mathrm{O}$ ); (3) the presence of setae (longer than the spines) on the anterior margin of segments 3 to 6 in P5 to P7 (fig. 8P-R); (4) the longer setae along the outer margin of the exopodite in uropod 3 (fig. 8S).

The colour of live specimens is brownish to grey with white opalescent eyes.

Variability. - The dorsal processes of the metasomites can be more (the Nigde population) or less developed (compare Vávra, 1905, pl. III fig. 10 and fig. 7P). Likewise, the number of setae implanted along the posterior margin of each metasome segment is largely variable, ranging from 3 to 10. Epimeres 2 and 3 in some populations have setae along the inferior margin, in others they have not. The number of setae on the interior surface of the basal segment in P6 and P7 varies from 0 to 2 and from 2 to 10 , respectively. In P5 these setae are usually absent. In most populations calceoli are present, in others (sampled in the province of Nigde, Turkey) calceoli are entirely absent. The flagellum of A2 can be more or less slender.

Material examined. -

Turkey: Prov. Kayseri, Soysali, near Develi, 25-V-1959, several specimens (Z.M.H., K.C.).

- do., Il Pinar, near Develi, 21-V-1959, 5 specimens (Z.M.H.).

- Prov. Koçaëli, Tavşanli, 13-IX-1969, 2 specimens (Z.M.A.).

- Prov. Ankara, small stream $10 \mathrm{~km} \mathrm{~W}$. of Balişih, $14 \mathrm{~km}$ N.E. of Kirrikale, alt. 830 m, 6-VI-1973, many specimens (Z.M.A.).

- Prov. Burdur, road towards Burdur Golü, V-1938, 5 specimens (K.C.).

- Prov. Konya, brooklet 2 km S. of Karaman, 4-VIII-1969, 17 specimens (Z.M.A.).

-- Prov. Nigde, spring Okoustchoketen, about $40 \mathrm{~km} \mathrm{S.} \mathrm{of}$ Nigde, 10-VI-1956, 5 specimens (M.C.S.N.).

- do., Nigde, 2-VIII-1947, 5 specimens (Z.M.H.).

- do., spring N. of Oloukichla, alt. $1400 \mathrm{~m}, 29-\mathrm{VI}-1953$, 10 specimens (M.C.S.N.).

- do., Çorak Dere, at Nigde, 3-VIII-1947, 16 specimens (Z.M.H.).

- do., spring at Nigde, 19-VI-1970, 8 specimens (M.C.S.N.).

- do., irrigation ditch, $6 \mathrm{~km} \mathrm{~N}$. of Aksaray, 31-VII-1969, 8 specimens, accompanied by G. cf. balcanicus (Z.M.A.).

- do., river flowing into Tüz Gölü, E. of Aksaray, about $1 \mathrm{~km}$ upstream of dam, 31-VII-1969, 7 specimens, accompanied by $G$. cf. balcanicus (Z.M.A.).

- do., confluent of Tüz Gölü, $6 \mathrm{~km}$ W. of Sultanhani (W. of Aksaray), 15-VI-1973, many specimens, many in precopulation (Z.M.A.).

Loc. typ. - Turkey, prov. Kayseri, Soysali, near Develi. Since we were unable to trace the type material of Vávra, 1905 , we thought it wise to select a neotype from topotypical material. The $\hat{o}$ neotype, $15 \mathrm{~mm}$, and many specimens from the type locality, have been deposited in the Zoolog. Museum und Institut, Hamburg. One specimen from the neotype series is deposited in the Karaman Collection, Titograd.

Distribution. - Central part of Asia Minor (see map I).

Remarks and affinities. - $G$. argaeus differs from $G$. mladeni, $G$. pavo and $G$. roeseli in the absence of long setae on the anterior margin of P5 to P7, and on the margin of the exopodite in uropod 3. It differs from $G$. goedmakersae in the shorter setation of $\mathrm{P} 3$ and $\mathrm{P} 4$ and of the outer margin of the exopodite in uropod 3. It differs from $G$. obnixus in the longer endopodite of uropod 3 and the presence of setae on the interior surface of the basis of P6 and P7. It differs from G. stojicevici in the shape of the epimeral plates and of the coxal plates 3 and 4.

Vávra, 1905, described the variety brachyurus. 


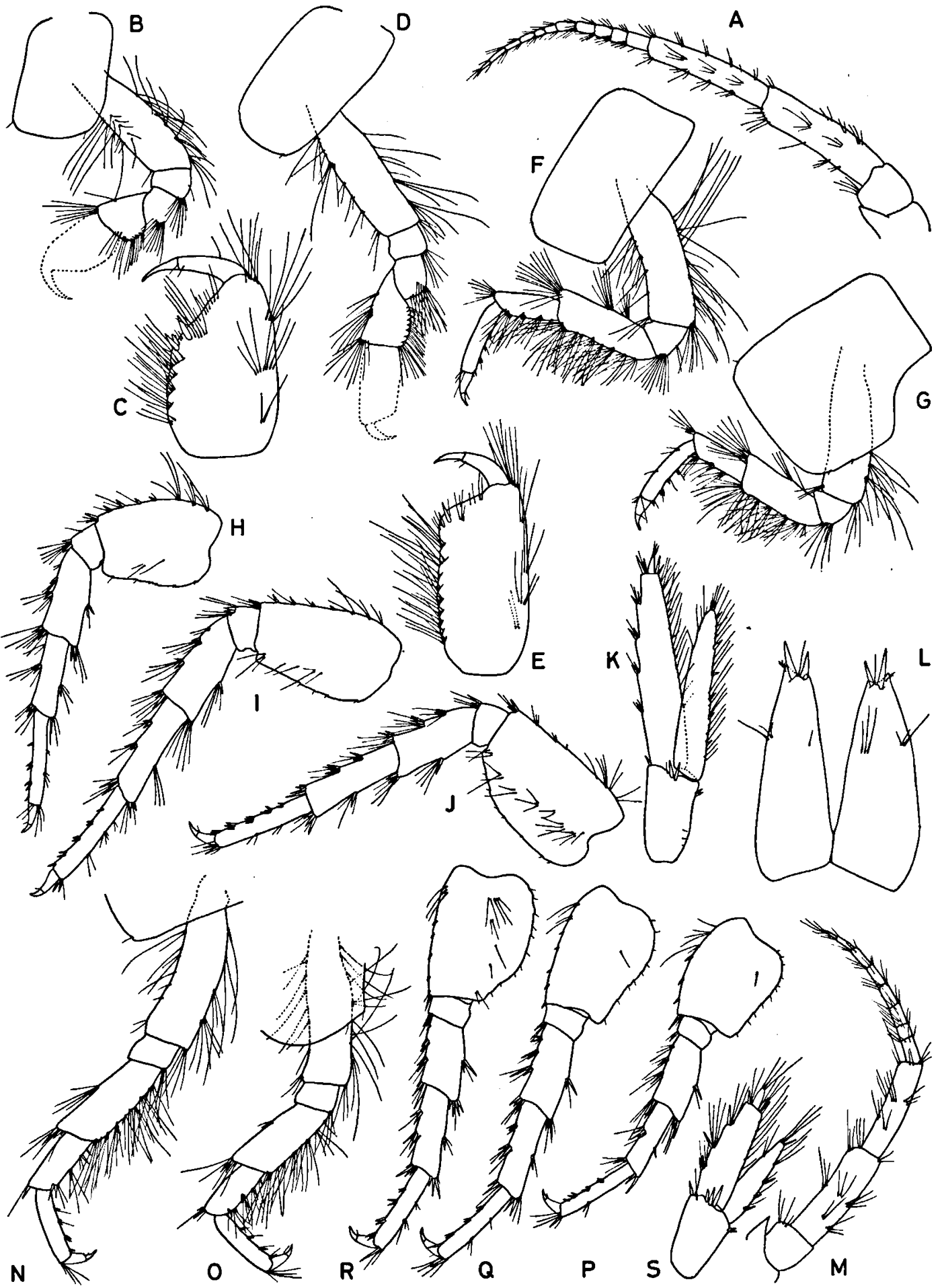

Fig. 8. A-L, Gammarus stojicevici (S. Karaman, 1929), $\$, 11 \mathrm{~mm}$, from Lake Krupac near Pirot, Yugoslavia. A, second antenna; B, first gnathopod; C, propodus of first gnathopod; D, second gnathopod; E, propodus of second gnathopod; F, third pereiopod; G, fourth pereiopod; H, fifth pereiopod; I, sixth pereiopod; J, seventh pereiopod; K, third uropod; L, telson.

M-S, Gammarus argaeus Vávra, 1905, $\$, 8.8 \mathrm{~mm}$, from vicinity of Burdurgöl, prov. Burdur, Turkey. M, second antenna; N, third pereiopod; $O$, fourth pereiopod; $P$, fifth pereiopod; $Q$, sixth pereiopod; $R$, seventh pereiopod; $S$, third uropod. 
In our opinion, this variety, characterized by its very short uropod 3 , is nothing but a specimen which lost, and later partly regenerated, its uropods. Therefore we consider this variety not valid.

S. \& G. Karaman, 1959, described G. (Fluviogammarus) argaeus burduri. Re-examination of this material and other material from the type locality, and a study of the original description of Vávra, however, learned that this subspecies is completely identical with the nominal form and thus not valid.

Ecology. - Usually found in slowly to moderately running water, often with a high amount of Ca-ions.

Gammarus stojicevici (S. Karaman, 1929) new rank. Figs. 8A-L, 9.

Refs.: Carinogammarus argaeus stojičeviči S. Karaman, 1929 92, fig. 7; 1931: 57.

Gammarus (Fluviogammarus) argaeus stojičeviči; S. \& G. Karaman, 1959: 198-201, figs. 10, 14, 40, 42 and 51.

Gammarus argaeus stojičevic̈i; G. Karaman, 1974: 9.

Diagnosis. - Large species with three dorsal processes. Antenna 2 slender, poorly setose, bearing calceoli. Pereiopods 3 and 4 poorly setose. Basal segment of pereiopods 6 and 7 with setae on inner surface; segments 3 to 6 without setae along the anterior margin. Outer margin of exopodite of uropod 3 very poorly setose. Epimeres 2 and 3 very sharp, armed with spines and setae.

Description. - Male: Maximum length observed $20 \mathrm{~mm}$. Metasome segments 1 to 3 each with a strong dorsomedian process. Urosome segments 1 to 3 moderately elevated, laterally compressed. The armature consists of one dorsomedian group and 2 dorsolateral groups of elements, each group consisting of 2 to 6 spines and 1 to 3 equally long setae (fig. 9P).

The lateral cephalic lobes are rounded; the eyes are ovoid or somewhat reniform, as long as or shorter than the diameter of the peduncle of $\mathrm{Al}$ (fig. 9A).

The first antenna is $1 / 3$ to $2 / 5$ times as long as the total body length, poorly setose. Peduncle segment 1 bears only one group of short setae along the ventral margin, segments 2 and 3 each bear 2 or 3 groups of setae along the ventral margin. The main flagellum is up to 34-segmented, the accessory flagellum 2- to 4-segmented (fig. 9B).

The second antenna is slender, poorly setose. The gland cone is little longer than half the third peduncle segment. Peduncle segments 4 and 5 are equally long, armed with 3 to 5 groups of setae along the ventral margin. The flagellum is slender, up to 14-segmented, dorsoventrally compressed. Each flagellar segment bears 1 or 2 small groups of short setae at the ventral margin, the setae being shorter than the length of the segments. Calceoli are always present (fig. 9C).

The second segment of the mandibular palp has 5 or 6 setae in its proximal portion and 8 to 10 setae in its distal portion. The third segment is armed with 26 to $28 \mathrm{D}$-setae, 4 to $6 \mathrm{E}$-setae, one group of A-setae and one group of B-setae (fig. 9D).

Gnathopods 1 and 2 are moderately setose, all setae being straight (fig. 9E, G). The propodus of P1 is armed with a medial palmar spine and 4 palmar angle spines, 2 on each side of the incision with the dactylus (fig. 9F, $\mathbf{F}^{\prime}$ ). The setation is short, poorly developed. The dactylus is slender. The propodus of P2 is armed with the usual medial palmar spine, 3 to 4 palmar angle spines and 3 spines at the inner surface near the palmar angle. The setation is short (fig. $9 \mathrm{H}, \mathrm{H}^{\prime}$ ). The dactylus is slender as well.

Pereiopods 3 and 4 are poorly setose, their segments 4 to 6 bearing very short setae at the posterior margin; the setae are always shorter than the diameter of the segments. On segments 5 and 6 these setae are intermixed with short spines. The setosity of P4 is as poor as that of P3 (fig. 9I, J). Coxal plates 1 and 2 have rounded inferior corners; coxal plates 3 and 4 have almost quadrangular inferior corners, caused by the quite straight inferior margin.

Pereiopods 5 to 7 are moderately long, armed with spines along the anterior margin of segments 3 to 6 . The basal segment of $\mathrm{P} 6$ and $\mathrm{P} 7$ bears setae on its interior surface. In P5 such setae are absent. The setae along the posterior margin of the basal segments are very short (fig. 9K-M). In all pereiopods the dactyli are moderately slender. 


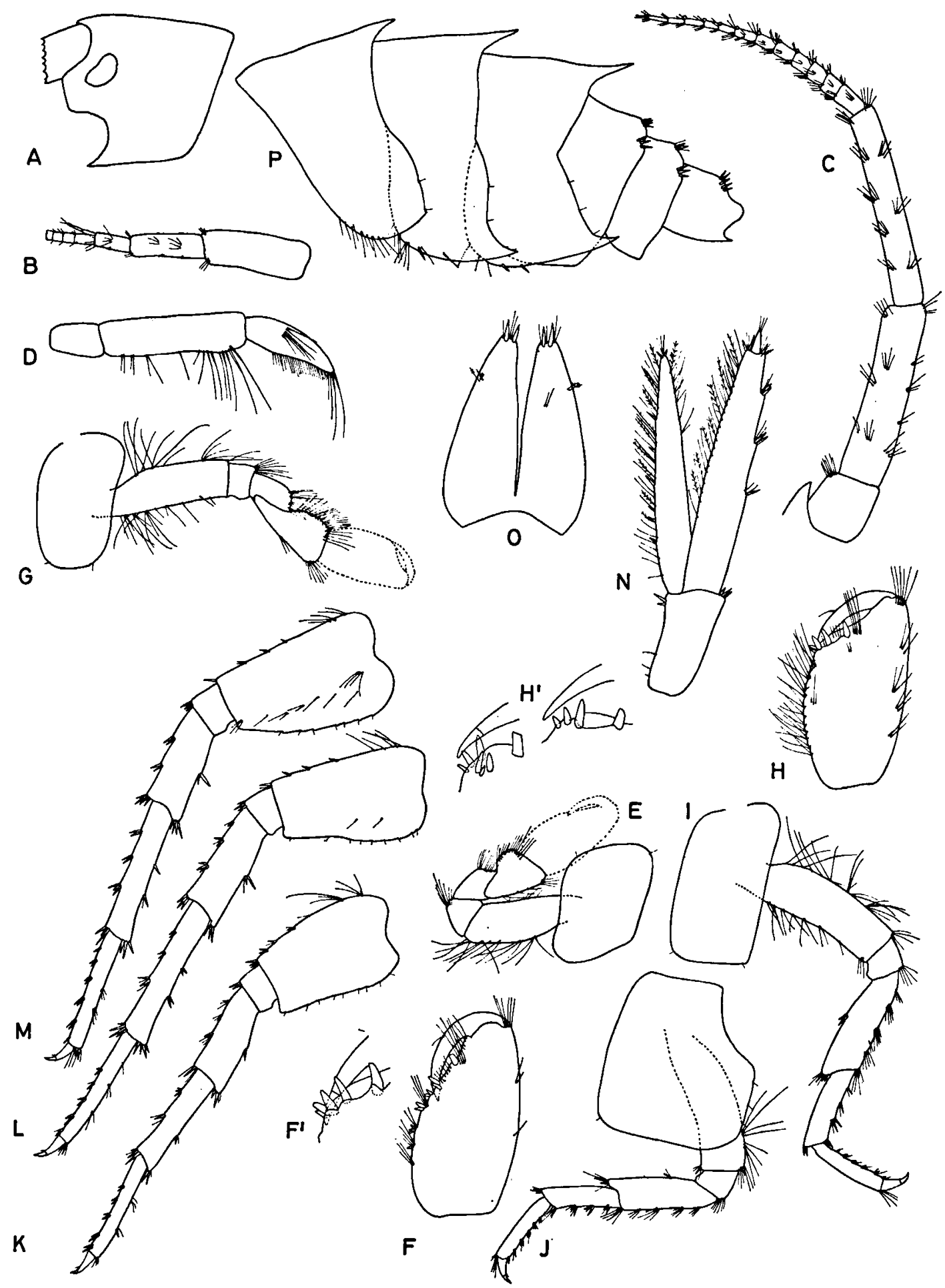

Fig. 9. A-P, Gammarus stojicevici (S. Karaman, 1929), ô, $16.1 \mathrm{~mm}$, from Lake Krupac near Pirot, Yugoslavia. A, head; B, first antenna; C, second antenna; D, mandibular palp; E, first gnathopod; F, propodus of first gnathopod; $F^{\prime}$, detail of palmar angle of the propodus of $\mathrm{Pl} ; \mathrm{G}$, second gnathopod; $\mathrm{H}$, propodus of second gnathopod; $\mathrm{H}^{\prime}$, detail of palmar angle of the propodus of P2, left inner face, right outer face; I, third pereiopod; J, fourth pereiopod; K, fifth pereiopod; L, sixth pereiopod; $M$, seventh pereiopod; $N$, third uropod; $O$, telson; $P$, meta- and urosome. 
Uropod 3 is moderately long, slender. The endopodite almost reaches the top of the first exopodal segment. The outer margin of the exopodite is very poorly armed with 3 or 4 groups of spines intermixed with some very short, simple setae. The outer margin of the endopodite is naked in its lower half, armed with plumose setae in its upper half. Most of the setae along the inner margins of exo- and endopodite are plumose (fig. 9N).

The posteroinferior corners of the second and third epimeral plates are sharply pointed. The inferior margin is armed with spines and setae. Epimere 1 has a rectangular posteroinferior corner and is armed with setae only (fig. 9P).

The telson lobes are very elongate, being more than 2.5 times as long as wide, tapering distally. The armature is scanty with 2 short distal spines and a few short setae intermixed with them. One or two short setae can sometimes be present on the dorsal surface of the lobes (fig. 9O).

Female: Clearly different from the male in many characters, viz.: (1) slightly more setose antenna 2, without calceoli; (2) more setose gnathopods 1 and 2, especially their propodi; (3) far more setiferous $\mathrm{P} 3$ and $\mathrm{P} 4$, the setae on segments 4 and 5 are as long as or longer than the diameter of the segments; (4) the presence of long setae along the anterior margin of segments 2 to 5 in P5 to P7; (5) the presence of setae on the inner surface of the basis in P5 to P7 (in males in P6 and P7 only); (6) a relatively shorter endopodite of uropod 3 (fig. $8 \mathrm{~A}-\mathrm{L}$ ).

The colour of live specimens is not known.

Variability. - Like in the other species the length of the metasome processes is rather variable. The same holds true for the number of setae implanted on the interior surface of $\mathrm{P} 6$ and $\mathrm{P} 7$ (or P5 to P7 in females), and the number of setae along the inferior margin of epimeres 2 and 3.

Material examined. -

Yugoslavia: East Serbia, spring near Bela Palanka, 19-VII1907, 10 specimens (K.C.).

- do., torrent near Bela Palanka, 7-VIII-1953, 8 specimens (K.C.).

- do., Barje, near Pirot, 2-VIII-1907, 4 specimens (K.C.).

- do., Lake Krupac, 25-VII-1961, many specimens (K.C.).

- do., Bela Palanka, 27-VII-1973, many specimens (M.C.S.N.).
- do., brooklet called Ralja, $10 \mathrm{~km} \mathrm{S.} \mathrm{of} \mathrm{Smederevo,} \mathrm{4-VIII-}$ 1973, several specimens (Z.M.A.).

Loc. typ. - Spring near Bela Palanka, East Serbia. The $\hat{o}$ holotype, $13.8 \mathrm{~mm}$, and 9 paratypes have been deposited in the Karaman Collection, Titograd.

Distribution. - East Serbia, Yugoslavia (see map I).

Remarks and affinities. - $G$. stojicevici differs from $G$. roeseli, $G$. pavo and $G$. mladeni in the absence of setae on the anterior margin of P5 to P7 and on the outer margin of the exopodite of uropod 3, and the poorly setose $\mathrm{P} 3$ and $\mathrm{P} 4$. The latter two characters differentiate it also from G. goedmakersae. It differs from G. obnixus in the presence of setae on the interior surface of the basal segments of $\mathrm{P} 6$ and $\mathrm{P7}$, and in the much longer endopodite of uropod 3. It differs from $G$. argaeus in its very sharply pointed epimeral plates and in the shape of coxal plates 3 and 4 . Females of $G$. stojicevici differ from females of all other species within the roeseli-group, except $G$. obnixus, because of the almost unarmed outer margin of the exopodite of uropod 3. They differ from females of $G$. obnixus in the much longer setation of $\mathrm{P} 3$ to $\mathrm{P} 7$.

The species was originally described as a subspecies of $G$. argaeus. Its morphological characters are indeed more closely resembling those of $G$. argaeus than those of any other species in the group. However, careful examination of many populations of both species revealed that the differences between argaeus and stojicevici are very stable; moreover, no transitional specimens were found.

Ecology. - Unknown.

Gammarus mladeni n. sp. Figs. 10, 11G-N.

Diagnosis. - Relatively large species with three dorsal processes. Metasome with dorsal setae. The second antenna is moderately slender, bearing calceoli. Pereiopods 3 and 4 moderately setose. Pereiopods 5 to 7 with short setae along the anterior margin. Epimeres very sharp, armed with spines and setae. Exopodite of third uropod with setose lateral margin. 


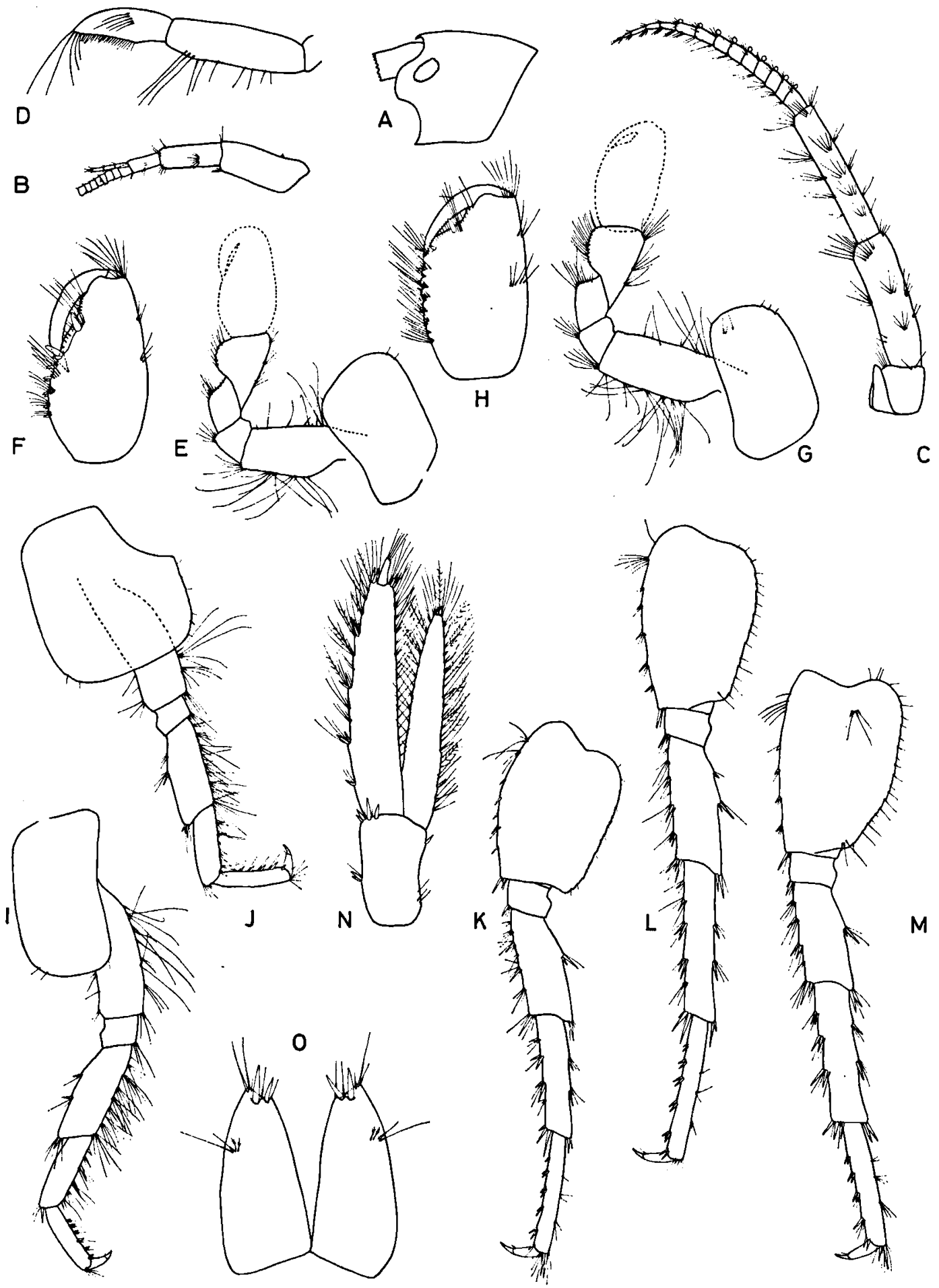

Fig. 10. A-O, Gammarus mladeni, n. sp., ô, $13.8 \mathrm{~mm}$, from Obruk, prov. Konya, Turkey. A, head; B, first antenna; C, second antenna; D, mandibular palp; E, first gnathopod; F, propodus of first gnathopod; $G$, second gnathopod; $H$, propodus of second gnathopod; I, third pereiopod; J, fourth pereiopod; $K$, fifth pereiopod; L, sixth pereiopod; M, seventh pereiopod; $N$, third uropod; $O$, telson. 
Description. - Male: Maximum length observed $18.5 \mathrm{~mm}$. Metasome segments 1 to 3 each bear several setae on the dorsal surface as well as a dorsomedian process. Moreover, 8 to 14 setae are implanted along the lateroposterior margin of each metasome segment. Urosomites 1 and 2 moderately elevated, slightly compressed laterally. The dorsal armature of the urosomites consists of one dorsomedian and two lateral groups of elements on each segment. The 2 or 3 spines and 1 to 4 setae that usually occur in these groups can be mutually replaced (fig. 11G).

The lateral cephalic lobes are rounded. The eyes are ovoid, as long as or slightly shorter than the diameter of the peduncle of A1 (fig. 10A).

The length of the first antenna varies from $2 / 5$ to $3 / 5$ of the body length. Peduncle segments 2 and 3 both have 2 groups of short setae along the ventral margin. The main flagellum (with up to 38 segments) and the accessory flagellum (with 3 to 5 segments) are poorly setose (fig. 10B).

The gland cone of antenna 2 reaches the top of the third peduncle segment. Peduncle segments 4 and 5 have 3 and 5 groups of setae, respectively, along the ventral margin; these setae are never longer than the diameter of the peduncle segments. The up to 14-segmented flagellum is moderately slender, dorsoventrally compressed, bearing calceoli. Reduced numbers of setae are implanted near the top of each flagellar segment, being nearly as long as the diameter of these segments (fig. 10C).

The second segment of the mandibular palp is armed with 3 or 4 setae in its proximal part and 5 or 6 setae in its distal part. Segment 3 bears 24 to $27 \mathrm{D}$-setae, one group of A-setae, one group of B-setae and 4 or 5 E-setae (fig. 10D).

Gnathopod 1 is poorly setose, the setae being straight (fig. 10E). The propodus is almost twice as long as wide, armed with a medial palmar spine, 2 or 3 palmar angle spines and several smaller spines along the posterior margin. The setation is poorly developed, short (fig. 10F). The setation of the second gnathopod is somewhat richer than that of the first (fig. 10G). The propodus is armed with a medial palmar spine, 3 or 4 palmar angle spines and 3 spines on the inner surface near the palmar angle. The posterior margin is armed with
8 to 10 groups of medium long setae, sometimes accompanied by some small spines (fig. 10H).

Pereiopod 3 is moderately setose; the posterior margin of segments 3 to 5 bears many groups of straight setae, nearly as long as the diameter of the segments. The posterior margin of segment 6 is provided with several pairs of short spines accompanied by short setae (fig. 10I). Pereiopod 4 is slightly less setose than $\mathrm{P}_{3}$ (fig. 10J). Coxal plates 1 to 4 have rounded inferior corners.

Segments 3 to 6 of pereiopods 5 to 7 bear short setae, intermixed with spines, at the anterior margin. Their basal segment has no setae on the interior surface (fig. 10K-M).

Uropod 3 is moderately long, its inner ramus being $4 / 5$ to $5 / 6$ of the first segment of the outer ramus. The outer margin of the exopodite is moderately setose, most of the setae being rather short and simple. The greater part of the setae along the other margins of endo- and exopodite is plumose (figs. $10 \mathrm{~N}$ and $11 \mathrm{H}$ ).

The shape of the epimeral plates changes from slightly pointed in the first to very sharp in the third. The inferior margin of epimeres 2 and 3 bears several setae intermixed with spines (fig. $11 G)$.

The telson lobes are about twice as long as wide, 'each lobe bearing 2 or 3 distal spines, accompanied by several medium long setae (up to twice as long as the spines). A few setae may be implanted on the dorsal surface of each lobe (figs. 10O, 11I).

Female: Apart from the normal sexual dimorphism like the absence of calceoli and of medial palmar spines, most characters resemble those of males (fig. $11 \mathrm{~J}-\mathrm{N}$ ). The exopodite of uropod 3 never bears plumose setae along its outer margin. Within the roeseli-group, females of this species are easily recognizable because of the presence of setae on the dorsal surface of the metasome segments.

Colour of live specimens unknown.

Variability. - Like in most members of this group, the length of the dorsal metasome processes is variable. Likewise, the number of setae on the dorsal surface of the metasome segments is largely variable. Usually the number varies from 5 or 6 on the first to 10 to 14 on the third metasome 


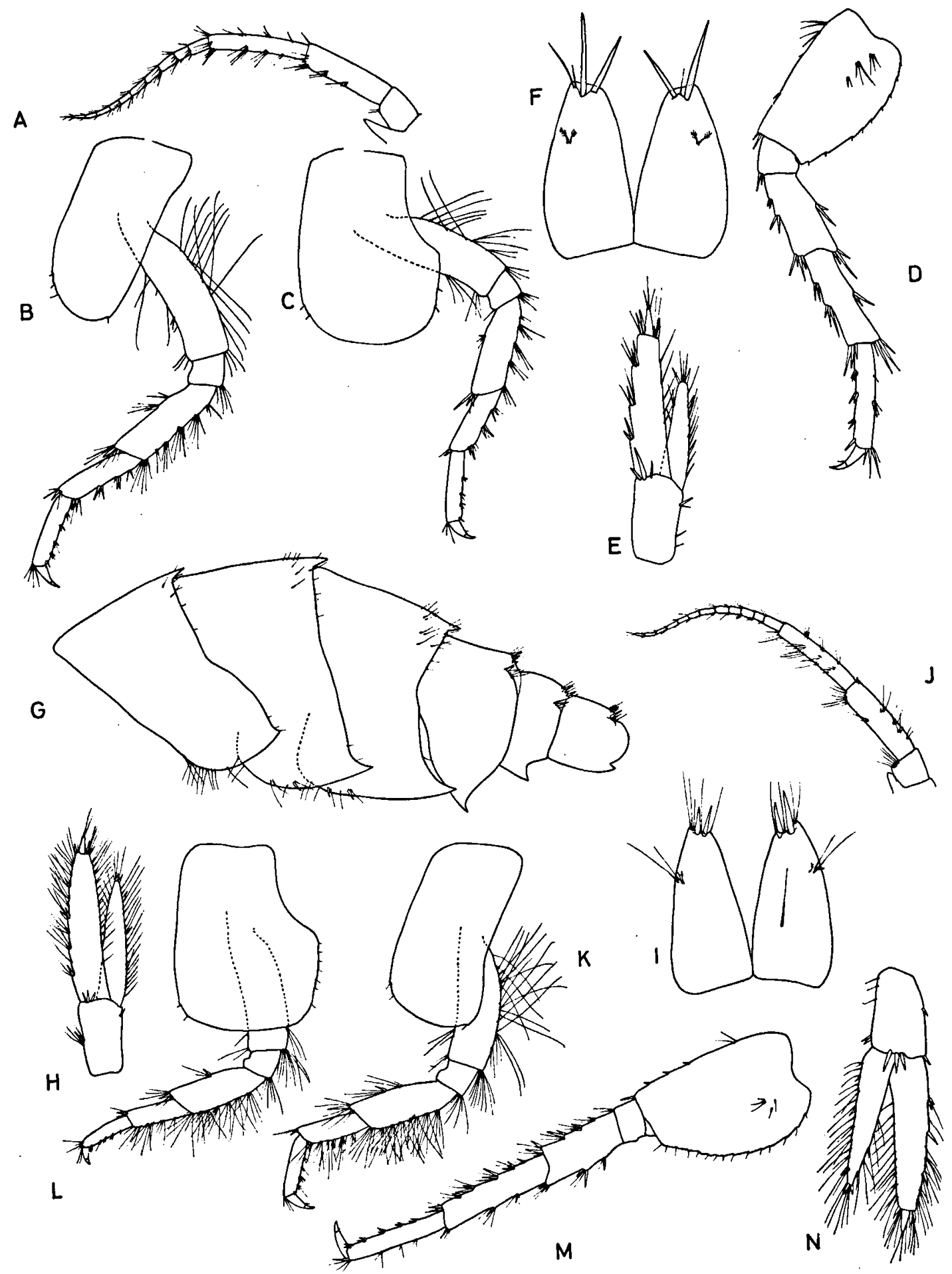

Fig. 11. A-F, Gammarus obnixus n. sp., \$, $8.6 \mathrm{~mm}$, from Lake Acigöl at Gemic, prov. Burdur, Turkey. A, second antenna; B, third pereiopod; C, fourth pereiopod; D, seventh pereiopod; E, third uropod; F, telson.

G-I, Gammarus mladeni n. sp., s, $8.1 \mathrm{~mm}$, from Obruk, prov. Konya, Turkey. G, meta- and urosome; H, third uropod; I, telson.

J-N, do., \&, $7.7 \mathrm{~mm}$. J, second antenna; K, third pereiopod; L, fourth pereiopod; M, seventh pereiopod; N, third uropod. 
segment. In the population from Kirşehir the number is reduced to 2 or 3 on each segment. In the population from Arsuz, dorsal setae are only occasionally found. Nevertheless, the presence of setae must be considered a stable character: They are already present in very small animals with a total length of $3.3 \mathrm{~mm}$. The length of the setae along the posterior margin of pereiopods 3 and 4 is also rather variable. In the population from Aksaray they are shorter than in most other populations. The posterior margin of the metasome segments sometimes makes an almost crenulated impression because of the setae implanted here.

Material examined, -

Turkey: Prov. Konya, road from Sultanhani to Konya, near Obruk, 11-VII-1973, many specimens (M.C.S.N., K.C.).

— do., Obruk, 6-VIII-1947, 2 specimens (Z.M.H.).

- do., between Sultanhani and Konya, 11-VII-1973, many specimens (M.C.S.N.).

- Prov. Nigde, Esmo Kaya, near Aksaray, 4-VIII-1947, 10 specimens (Z.M.H.).

- do., Aksaray, 5-VIII-1947, 5 specimens (Z.M.H.).

- Prov. Kirşehir, surroundings of Kirşehir, 19-V-1959, 20 specimens, accompanied by G. cf. balcanicus (Z.M.H.).

- do., spring near Kirşehir, 19-V-1959, 10 specimens (Z.M.H.).

- Prov. Hatay (= Antakya), Arsuz, II-1946, 12 specimens (Z.M.H.).

Loc. typ. - Turkey, prov. Konya, road from Sultanhani to Konya, near Obruk. The $\hat{o}$ holotype, $13.8 \mathrm{~mm}$, and many paratypes have been deposited in the collections of the Museo civico di Storia naturale, Verona. Two paratypes have been deposited in the Karaman Collection, Titograd.

Distribution. - Southern and southeastern part of Turkey (see map II).

Remarks and affinities. - G. mladeni differs from G. goedmakersae, G. obnixus, G. stojicevici and $G$. argaeus in the presence of setae on the anterior margin of P5 to P7. It differs from G. pavo and $G$. roeseli in its poorly setose antenna 2 and its sharp epimeres. It differs from all other members of this group by the presence of setae on the dorsal surface of metasomites 1 to 3 .

This species is dedicated to Dr. Mladen Karaman who collected part of the material studied.

Ecology. - Unknown.

Gammarus obnixus n. sp. Figs. 11A-F, 12.

Diagnosis. - Medium large species with three dorsal processes. Antenna 2 very slender, poorly setose, without calceoli. Pereiopods 3 and 4 poorly setose, pereiopods 5 to 7 without setae along the anterior margin. Exopodite of uropod 3 poorly setose. Epimeres moderately pointed, armed with spines and short setae.

Description. - Male: Maximum length observed $14 \mathrm{~mm}$. Metasome segments 1 to 3 each have a dorsomedian process. Setae are absent on the dorsal surface of the metasome segments; 4 or 5 short setae are implanted along the lateroposterior margin of these segments. Urosome segments 1 and 2 are slightly elevated, segment 3 is flat. Each segment is armed with a middorsal group of elements and a lateral group on each side, consisting of 1 to 3 spines intermixed with 0 to 3 short setae (fig. 12P).

The lateral cephalic lobes have rounded to quadrangular corners. The eyes are slightly reniform, as long as or shorter than the diameter of the peduncle of A1 (fig. 12A).

The first antenna attains about $3 / 5$ of the body length. Peduncle segment 1 only bears some distal groups of setae, peduncle segments 2 and 3 each have 2 or 3 ventral groups of short setae. The main and accessory flagella have 23 to 30 and 2 to 4 segments, respectively (fig. 12B).

The second antenna is slender and poorly setose. The gland cone is as long as the third segment. Peduncle segments 4 and 5 bear 3 or 4 , and 4 or 5 groups of short setae, respectively, along the ventral margin. These setae are always shorter than the diameter of the segments. The flagellum is very slender, up to 14-segmented, not compressed. The setae implanted near the top of each flagellar segment are shorter than the length of these segments. Calceoli are absent (fig. 12C).

Segment 2 of the mandibular palp bears 2 to 4 setae in its proximal part and 10 to 14 setae in its distal part. Segment 3 is armed with 27 to $30 \mathrm{D}$ setae, 4 to 6 E-setae, 2 groups of A-setae and 2 groups of B-setae (fig. 12D).

Gnathopods 1 and 2 are moderately setose, with straight setae only (fig. 12E, G). The propodus of both gnathopods is elongate, twice as long as wide; the armature does not show important differences with that described for $G$. roeseli (fig. 12F, H). 


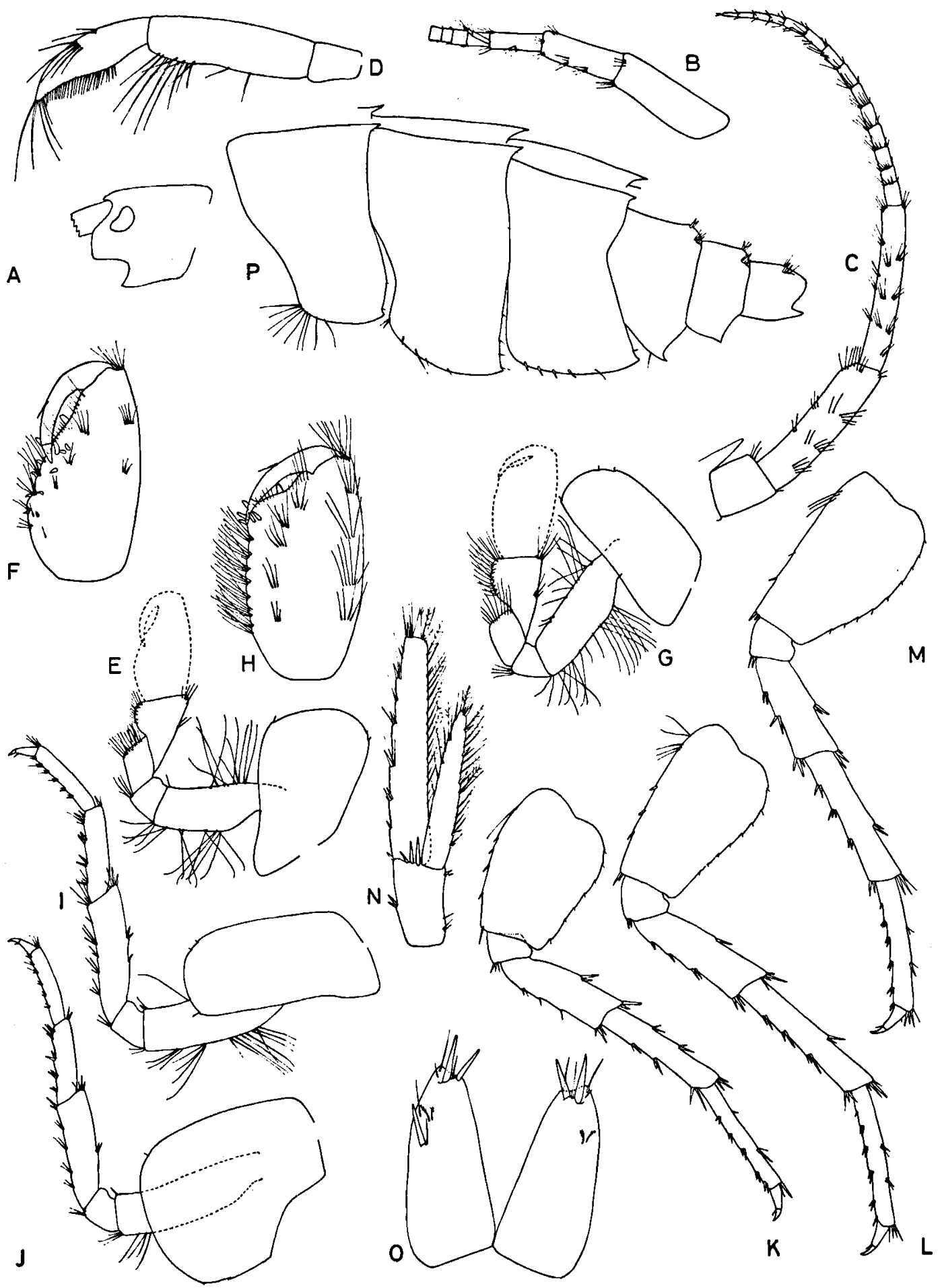

Fig. 12. A.P, Gammarus obnixus n. sp., ô, $13.2 \mathrm{~mm}$, from Lake Acigöl at Gemic, prov. Burdur, Turkey. A, head; B, first antenna; C, second antenna; D, mandibular palp; E, first gnathopod; F, propodus of first gnathopod; G, second gnathopod; H, propodus of second gnathopod; I, third pereiopod; J, fourth pereiopod; K, fifth pereiopod; L, sixth pereiopod; $M$, seventh pereiopod; $N$, third uropod; $O$, telson; $P$, meta- and urosome. 
The setation of pereiopods 3 and 4 is very poor. On the merus some setae can be found along the posterior margin but these setae are always much shorter than the diameter of the merus. The carpus and propodus are provided with several pairs of short spines intermixed with short setae. P4 is slightly less setose than $\mathrm{P} 3$ (fig. 12I, J). Coxal plates 1 to 4 have rounded inferior corners.

Apart from the short setae along the posterior margins of the basal segment, the armature of pereiopods 5 to 7 almost completely consists of short spines along the posterior and anterior margins. The interior surface of the basal segment is unarmed (fig. $12 \mathrm{~K}-\mathrm{M}$ ). In all pereiopods the dactyli are moderately slender.

Uropod 3 is moderately long. Its endopodite is $3 / 5$ to $2 / 3$ of the exopodite. The outer margin of the exopodite is sparsely armed with 6 to 8 groups of short spines intermixed with some simple setae (being little longer than the spines). The inner margin of the exopodite and both margins of the endopodite are armed with short plumose setae. On the inner margin of the endopodite some additional spines can be found (fig. $12 \mathrm{~N})$.

The posteroinferior corners of the epimeral plates are rectangular (in epimere 1) to moderately pointed (in epimere 2). The inferior margins of epimeres 2 and 3 are armed with spines, sometimes intermixed with setae (fig. 12P).

The telson lobes are twice as long as wide, poorly armed, each lobe with a distal group of 1 or 2 spines intermixed with 2 to 4 shorter or equally long setae. The dorsal surface of the lobes is usually unarmed, occasionally one spine and/or 1 or 2 setae occur (fig. 12O).

Female: Apart from the usual dimorphism in the gnathopods and antenna 2, the following differences could be observed from the other sex: (1) the slightly longer setation of the peduncle of antenna 2; (2) the longer setation of pereiopods 3 and 4; (3) the presence of setae on the inner surface of the basis in P7; (4) the relatively shorter endopodite of uropod 3 , being only $1 / 2$ to $3 / 5$ as long as the exopodite (see fig. 11A-F).

The colour of live specimens is unknown.

Variability. - The processes on metasomites 1 to
3 are usually well developed although not very high. The carination can vary within one population (from Lake Acigöl, Gemic). In the population from Lake Dinar Karakugu, Pinarbaşi, specimens can be found in which the processes are so small that they are virtually absent. The shape of the epimeres is variable, more or less sharp. In some populations (e.g. from Lake Acigöl) the inferior margins of the epimeres are armed with spines, in others (e.g. Lake Dinar Karakugu, Pinarbaşi) with spines and setae. The eyes are rather variable in shape.

Material examined. -

Turkey: Prov. Afyon, Lake Acigöl at Gemic, 5-V-1959, many specimens (Z.M.H., K.C.).

- Prov. Konya, well near Lake Dinar Karakugu at Pinarbaşi, 7-V-1959, many specimens, accompanied by Gammarus agrarius (G. Karaman) and $G$. pavo n. sp. (Z.M.H.).

- do., Lake Dinar Karakugu at Düdenler, 7-V-1959, 15 specimens accompanied by Gammarus agrarius (G. Karaman) and G. pavo n. sp. (Z.M.H.).

- Prov. Denizli, beach of Lake Acigöl at Çardak, 6-VII1973, many specimens (M.C.S.N.).

- Prov. Isparta, vicinity of Lake Egridir or Lake Beyşehir, summer 1973, 4 \% $\%$ (M.C.S.N.).

Loc. typ. - Turkey, Province of Afyon, Lake Acigöl at Gemic. The of holotype, $13.2 \mathrm{~mm}$, and many paratypes have been deposited in the Zoolog. Museum und Institut, Hamburg. Four paratypes have been deposited in the Karaman Collection, Titograd.

Distribution. - The species appears to be restricted to the lake district in the central part of Turkey (see map II).

Remarks and affinities. - G. obnixus differs from G. mladeni, $G$. pavo, and $G$. roeseli in the absence of setae on the anterior margin of P5 to P7 and the short setation of $\mathrm{P} 3$ and P4. It differs from G. goedmakersae in the short setation of P3 and $\mathrm{P} 4$ and in the poorly setose outer margin of the exopodite of uropod 3. It differs from $G$. argaeus and $G$. stojicevici in its much shorter endopodite of uropod 3 and the absence of setae on the inner surface of the basis of P6 and P7. Females of $G$. obnixus differ from females of all other species within the roeseli-group, except $G$. goedmakersae, because of the absence of setae on the anterior margins of P5 to P7. They differ from females of $G$. goedmakersae in the much shorter setation of uropod 3 and pereiopods 3 and 4 . 
The name obnixus (= Latin, obstinate) alludes to the ability of the species to live in the upper part of the littoral zone of lakes where wave action is rather hard.

Ecology. - Usually found in the littoral zones of lakes with a raised sodium content.

\section{REFERENCES}

BARNARD, J. L., 1958. Index to the families, genera and species of the gammaridean Amphipoda (Crustacea). Occ. Pap. Allan Hancock Fdn., 19: 1-145.

BERNER, L., 1972. Liste régionale des Gammaridés (CrustacésAmphipodes). Bull. Soc. Étude Sci. nat. Vaucluse, 1970/ 1972: 97.99.

BesCH, W., 1968. Zur Verbreitung der Arten des Genus Rivulogammarus in Fliessgewässern Nordbadens und Südwürttembergs. Beitr. naturk. Forsch. SüdwDtl., 27 (1): 27-33.

Cáráusu, S., E. Dobreanu \& C. Manolache, 1955. Amphipoda, forme salmastre şi de apâ dulce. Fauna Repub. pop. rom., Crustacea, 4 (4): 1-407.

Chevreux, Ed. \& L. Fage, 1925. Amphipodes. Faune France, 9: 1.488.

Garbini, A., 1902. Una specie nuova di Gammarus (G. tetracanthus) nel lago Müggel. Zool. Anz., 25: 153-154.

Gervais, M., 1835. Note sur deux espèces de Crevettes qui vivent aux environs de Paris. Annls. Sci. nat. (Zool.), (2) 4: $127-128$.

HaRtwig, W., 1899. Die niederen Crustaceen des Müggelsees und des Saaler Boddens während des Sommers 1897. ForschBer. biol. Stn. Plön, 7: 29-43.

Heinze, K., 1932. Fortpflanzung und Brutpflege bei Gammarus pulex $\mathrm{L}$. und Carinogammarus roeselii Gerv.: 398-440 (Inaugural-Dissertation, Berlin).

HelleR, C., 1865. Kleine Beiträge zur Kenntniss der Süsswasser-Amphipoden. Verh. zool.-bot. Ges. Wien, 15: 979.985, pl. XVII.

HerBST, J. F. W., 1796. Versuch einer Naturgeschichte der Krabben und Krebse nebst einer systematischen Beschreibung ihrer verschiedenen Arten, 2: i-viii, 1-225, pls. XXII-XLVI (G. A. Lange, Berlin \& Stralsund).

HINZ, W., 1975a. Vorkommen von Gammarus (Amphipoda) im Raum Düsseldorf-Ratingen. Decheniana, 128: 107111.

, 1975b. Beitrag zur Wirbellosen-Fauna der Gewässer im Raum nördlich und östlich von Düsseldorf-Ratingen. Natur Heimat, 35 (2): 25-30.

Hoffmand, J., 1963. Faune des Amphipodes du GrandDuché de Luxembourg. Archs. Inst. gr.-duc. Luxemb., 29: 77-128.

Hösıus, A., 1850. Über die Gammarus-Arten der Gegend von Bonn. Arch. Naturgesch., 16: 233-248.

JAżDżEWSKI, K., 1975. Morfologia, taksonomia i występowanie w Polsce kiełży z rodzajów Gammarus Fabr. i Chaetogammarus Mart. (Crustacea, Amphipoda). Acta Univ. Lodz., 1975: 1-187 [Thesis, University of Lodz].

Kallnbach, M. E. \& M. P. D. Meijering, 1970. Die Gammariden der Haune. Beitr. Naturk. Osthessen, 2: 51.60 .

Karaman, G. S., 1974. Crustacea, Amphipoda. Cat. faun. Jugoslaviae, 3 (3): 1-42.
Karaman, S., 1929. II. Beitrag zur Kenntnis der Amphipoden Jugoslaviens. Glasn. zemalj. Mus. Bosni Herceg., 41: 83-99.

- 1931. III. Beitrag zur Kenntnis der Amphipoden Jugoslaviens, sowie einiger Arten aus Griechenland. Prirodosl. Razpr., 1 : 31-66.

—_, 1935. VII. Beitrag zur Kenntnis der Süsswasseramphipoden. Zool. Anz., 110 (5/6): 125-130.

Karaman, S. \& G. S. Karaman, 1959. Gammarus (Fluviogammarus) triacanthus Schäferna, argaeus Vávra und roeselii Gervais am Balkan. Izd. Zav. Ribarst. N.R. Maked., 2 (9): 183-211.

Karaman, G. S. \& S. Pinkster, 1977. Freshwater Gammarus species from Europe, North Africa and adjacent regions of Asia (Crustacea-Amphipoda). Part I. Gammarus pulex-group and related species. Bijdr. Dierk., 47 (1): 1.97.

Koch, C. L. (in PAnzer, 1836). Deutschlands Crustaceen, Myriapoden und Arachniden. Ein Beitrag zur Deutschen Fauna, 5 (1): $1-24$ (G. A. W. Herrich-Schäfer, Regensburg).

LAtreille, P. A., 1808. Genera Crustaceorum et Insectorum secundum ordinem naturalem in familias disposita iconibus exemplisque plurimis explicata, 1: i-xviii, 1-302 (A. Koenig, Parisiis \& Argentorati).

LiNNAEUS, C., 1758. Systema naturae (ed. 10), 1: 1.824 (L. Salvii, Holmiae).

Meijering, M. P. D., 1971. Die Gammarus-Fauna der Schlitzländer Fliessgewässer. Arch. Hydrobiol., 68 (4): 575-608.

—-, 1972. Experimentelle Untersuchungen zur Drift und Aufwanderung von Gammariden in Fliessgewässern. Arch. Hydrobiol., 70 (2): 133-205.

Pacaud, A., 1945. Données d'ensemble sur la répartition géographique des Gammares dans les eaux continentales françaises. C. r. Séanc. Soc. Biogéogr., 188/190: 1-7.

- , 1952. Nouvelle revue de la distribution géographique des Gammares dans les eaux continentales françaises. C. r. Séanc. Soc. Biogéogr., 252/253: 95-111.

Pinkster, S., 1973. The Echinogammarus berilloni-group, a number of predominantly Iberian amphipod species (Crustacea). Bijdr. Dierk., 43 (1): 1-39.

Rösel von Rosenhof, A. J., 1755. Der monathlich herausgegebenen Insecten-Belustigung, 3 (62): 351-357, Suppl. Tab. LXII figs. 1-7 (J. J. Fleischmann, Nürnberg).

Roux, A. L., 1969. L'extension de l'aire de répartition géographique de Gammarus roeseli en France. Nouvelles données. Annls. Limnologie, 5 (2): 123-127.

SCHÄFERNA, K., 1922. Amphipoda balcanica, spolu s poznámkami o jiných sladkovodních Ampjipodech. Mém. Soc. r. Sci. Bohême (Cl. Sci.), 1921/1922 (12): 1-109, pls. I-II.

— 1926. Gammaridea ze sbĕrů prof. Dra Julia Komárka v Makedonii. (Les Gammarides de la Macédoine de la collection de $\mathbf{M}$. le prof. J. Komárek). Mém. Soc. $\mathbf{r}$. Sci. Bohême (Cl. Sci.), 1925 (10): 1-15.

Schellenberg, A., 1937. Kritische Bemerkungen zur Systematik der Süsswassergammariden. Zool. Jb. (Syst.), 69: 469-516.

- 1942. Flohkrebse oder Amphipoda. Tierwelt Dtl., 40: i-iv, 1-252.

1943. Die Amphipoden des Ochridasees. Zool. Anz., 143: 97.103 
Stebbing, T. R. R., 1906. Amphipoda, 1. Gammaridae. Tierreich, 21: i-xxxix, 1-806.

StraškrabA, M., 1953. Note préliminaire sur la distribution du genre Gammarus dans la Tchécoslovaquie. Věst. čsl. zool. Spol., 17 (3): 212-227.

- 1958. Beitrag zur Kenntnis der Verbreitung der Amphipoden in der Tschechoslowakei aus dem zoogeographischen Gesichtspunkt. Acta Univ. Carol., 1958 (2): 197-208.

-, 1959. Prispevek k Poznani fauny Amphipod Slovenska. Biologia Bratisl., 14 (3): 161-172.

- 1967. Amphipoda. In: J. Illies (ed.), Limnofauna Europaea: 202-209 (Gustav Fischer, Stuttgart).

Vávra, V., 1905. Rotatorien und Crustaceen. In: A. PeNTHER \& E. ZEDERBAUER, Ergebnisse einer naturwissen- schaftlichen Reise zum Erdschias-Dagh (Kleinasien). I. Zoologischer Teil. Annln. naturh. Mus. Wien, 20: 106113, pl. III.

VoвIs, H., 1973. Rheotaktisches Verhalten einiger GammarusArten bei verschiedenem Sauerstoffgehalt des Wassers. Helgoländer wiss. Meeresunters., 25 (4): 495-508.

Vornatscher, J., 1965. Ordnung Amphipoda, Flohkrebse. Cat. Faun. Austriae, 8: 1-3.

WAGLER, E., 1937. Crustacea (Krebstiere). Tierwelt Mitteleur., 2, Amphipoda: 188-213.

Wautier, J. \& A. Roux, 1959. Présence de Gammarus (Rivulogammarus) roeselii Gervais 1835, dans la basse vallée de la Saône. Bull. mens. Soc. linn. Lyon, 28 (4): 118-119.
LIST OF (SUB)SPECIFIC NAMES USED IN THIS PAPER characters)

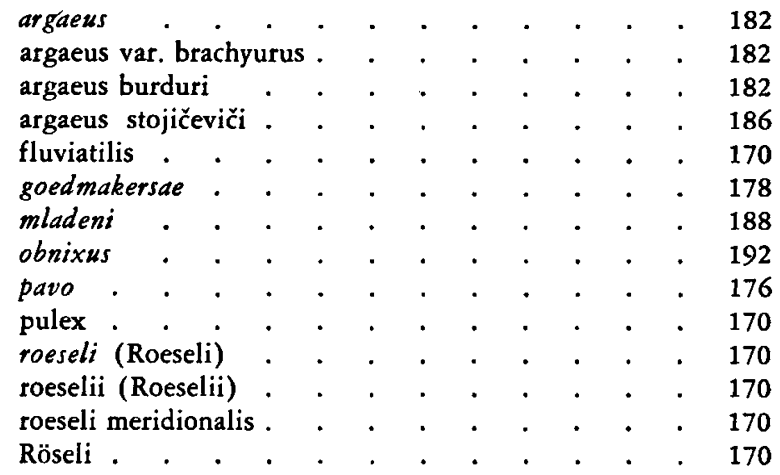

(names in current use are printed in italics, synonyms in roman

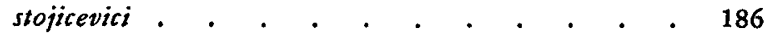

tetracanthus . . . . . . . . . . . 170

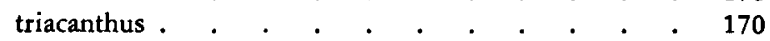

triacanthus graecus . . . . . . . . : . 170

triacanthus f. montenegrinus . . . . . . 170

triancanthus nisiae . $\quad . \quad . \quad . \quad . \quad . \quad . \quad . \quad .170$

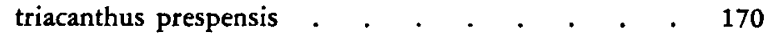

triacanthus semiarmatus . . . . . . . . . 170

triacanthus strumicae . . . . . . . . 170

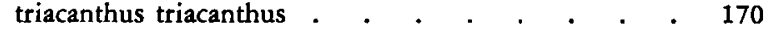

triacanthus $f$. vardarensis . . . . . . . 170

vardarensis . . . . . . . . . . . . . 170

vardarensis semiarmatus . . . . . . . . 170

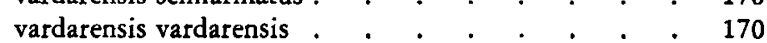

